\title{
Julius Kaljuvee, Ivan Reinwald, and Estonian pioneering ideas on meteorite impacts and cosmic neocatastrophism in the early 20th century
}

\author{
Grzegorz Racki ${ }^{1, *}$, Tõnu Viik ${ }^{2}$ and Väino Puura ${ }^{3, \dagger}$ \\ ${ }^{1}$ Faculty of Earth Sciences, University of Silesia, Będzińska Str. 60, 41-200 Sosnowiec, Poland \\ 2 Tartu Observatory, University of Tartu, Tõravere, 61602 Tartumaa, Estonia \\ ${ }^{3}$ Faculty of Science and Technology, University of Tartu, Vanemuise 46, 51014 Tartu, Estonia
}

Received: 15 January 2018 / Accepted: 5 July 2018

\begin{abstract}
The article comprehensively presents little known Estonian contribution to the recognition of first meteorite impact structures in Europe, related to works of Julius Kaljuvee (Kalkun; 1869-1940) and Ivan Reinwald (Reinwaldt; 1878-1941). As an active educator specialized in geoscience, Kaljuvee was the first to hypothesize in 1922 that Kaali lake cirque in Saaremaa Island, Estonia, was created by meteorite impact. Thanks to mining engineer Reinwald, this assumption was accepted since 1928 due to the exhaustive field and borehole works of the latter (also as a result of exploration by several German scholars, including renowned Alfred Wegener). The impact origin of Kaali structure was proved finally in 1937 by finding of meteoritic iron splinters (as the first European site). Reinwald was not only outstanding investigator of meteorite cratering process, but also successful propagator of the Estonian discoveries in Anglophone mainstream science in 1930s. In addition, in his 1933 book, Kaljuvee first highlighted an impact explanation of enigmatic Ries structure in Bavaria, as well as probable magmatic activation in distant regions due to "the impulse of a giant meteorite". He also outlined ideas of the inevitable periodic cosmic collisions in geological past ("rare event" theory nowadays), and resulting biotic crises. In a general conceptual context, the ideas of Kaljuvee were in noteworthy direct or indirect link with concepts of the great French naturalists - Laplace, Cuvier and Élie de Beaumont. However, some other Kaljuvee's notions, albeit recurrent also later in geoscientific literature, are queer at the present time (e.g., the large-body impact as a driving force of continental drift and change the Earth axis, resulting in the Pleistocene glaciation). Thus, the Kaljuvee thought-provocative but premature dissertation is rather a record of distinguishing erudite activity, but not a real neocatastrophic landmark in geosciences history. Nevertheless, several concepts of Kaljuvee were revived as the key elements in the current geological paradigm.
\end{abstract}

Keywords: J. Kaljuvee / I. Reinwald / Kaali impact crater field / meteorite impacts / neocatastrophism / history of geology

Résumé - Julius Kaljuvee, Ivan Reinwald et des idées pionnières estoniennes sur les impacts des météorites et le néocatastrophisme cosmique au début du $20^{\mathbf{e}}$ siècle. L'article présente de manière exhaustive les contributions estoniennes à peine connues à la reconnaissance des premières structures d'impact de météorites en Europe, liées aux travaux de Julius Kaljuvee (Kalkun; 1869-1940) et Ivan Reinwald (Reinwaldt; 1878-1941). En tant qu'éducateur actif spécialisé en géosciences, Kaljuvee a été le premier à émettre l'hypothèse qu'en 1922, le cirque du lac Kaali, sur l'île de Saaremaa, en Estonie, a été créé par l'impact d'une météorite. Grâce à l'ingénieur minier Reinwald, cette hypothèse a été acceptée depuis 1928 en raison des travaux de terrain et de forage exhaustifs de cette dernière (également à la suite de l'exploration de plusieurs chercheurs allemands, dont le célèbre Alfred Wegener). L'origine d'impact de la structure de Kaali a été prouvée finalement en 1937 par la découverte d'éclats de fer météoritiques (en tant que premier site européen). Reinwald était non seulement un chercheur exceptionnel du processus de cratérisation des météorites, mais aussi un propagateur couronné de succès des découvertes estoniennes dans la science anglophone dominante des années 1930. En outre, dans son livre de 1933, Kaljuvee a

*Corresponding author: racki@us.edu.pl

$\dagger$ Deceased author. 
d'abord mis en évidence une explication de l'impact de la structure énigmatique de Ries en Bavière, ainsi qu'une probable activation magmatique dans des régions lointaines, due à «l'impulsion d'une météorite géante ». Il a également exposé les idées sur les inévitables collisions cosmiques périodiques du passé géologique (théorie des «événements rares » de nos jours) et les crises biotiques qui en résultent. Dans un contexte conceptuel général, les idées de Kaljuvee étaient en lien direct ou indirect avec les concepts des grands naturalistes français-Laplace, Cuvier et Élie de Beaumont. Cependant, d'autres notions de Kaljuvee, quoique récurrentes aussi plus tard dans la littérature géoscientifique, sont étranges à l'heure actuelle (par exemple, l'impact des grands corps comme force motrice de la dérive des continents et change l'axe terrestre, entraînant la glaciation du Pléistocène). Ainsi, la dissertation pensante mais prématurée de Kaljuvee est plutôt un enregistrement de l'activité érudite distinctive, mais pas un véritable repère néocatastrophique dans l'histoire des géosciences. Néanmoins, plusieurs concepts de Kaljuvee ont été réaffirmés en tant qu'éléments clés du paradigme géologique actuel.

Mots clés : J. Kaljuvee / I. Reinwald / champ de cratère d'impact de Kaali / impacts de météorites / le néocatastrophisme / histoire de la géologie

\section{Introduction}

Meteor (or Barringer) Crater in central Arizona (Colorado Plateau, USA), the first historically recognized meteorite impact structure, is presently understood as an undoubted, ideally preserved signature of cosmic collision on the surface of the Earth that significantly influenced our understanding of geological history, and its links with the whole solar system (Marvin, 1986; Hoyt, 1987; French, 1998; Kölbl-Ebert, 2015; Powell, 2015). During first decades of 20th century, however, the origin the mysterious crater-like hill (Fig. 1), variously referred to as Coon Butte, Coon Mountain or Meteorite Mountain at the time, remained still an enigma (Drake, 1985; Hoyt, 1987; Powell, 2015). Since its first scientific description by Foote (1891), this bowl-shaped depression was thought to be a unique natural curiosity. Coon Butte was tentatively interpreted by Grove K. Gilbert, the great authority of American geology, as a record of an extreme explosion of volcanogenic vapors (Eifel maar-type-; Gilbert, 1896; idea developed by Keyes, 1907), only accidentally accompanied by meteorite shower. In fact, already Foote stressed richness of undoubtedly meteoritic iron masses in the crater surroundings, which were called as the Canyon Diablo meteorite. Owing to the highly startling co-occurrence, the Coon Mountain was since 1905 alternatively highlighted as an extraordinary meteorite scar (see Hoyt, 1987 for detailed review), and the fascinating idea was distributed also among European geoscientists (see below; Fig. 1). The designation as Meteor Crater was successfully introduced soon by Fairchild (1907), although the name is flawed from the point of view of modern terminology (i.e., in fact it is the meteorite crater).

Significantly in the cognitive context, prior to the report on the meteorite-bearing crater near Odessa in Texas by Sellards (1927), the Meteor Crater was the sole known terrestrial structure of this puzzling kind, also in the planetary scale (e.g., Gore, 1909; Günther, 1911; Bergeron, 1913; Nininger, 1933; Spencer, 1933). On the other hand, since Halley's visionary connotation (1707), several putative sites of extraterrestrial body falls were conjecturally proposed by European scientists (mostly "cometary scars": see Schechner Genuth, 1997; Tab. 1). With reference to the Meteor Crater, Högbom (1910) suggested meteorite impact origin for two Swedish lake basins, first in the connection with European cirque-like structures.
The present paper is dedicated to insufficiently known Estonian contribution to the pioneer recognition of meteorite craters in Europe, related to works of Julius Kaljuvee and Ivan Reinwald. In particular, Kaljuvee (earlier Kalkun) was noted in several papers as the first proponent of meteoritic origin for a Kaali lake (Fig. 2) and related group of small craters on the Baltic island of Oesel (=Saaremaa; $c f$. Kaali Meteorite Crater Field), as early as in 1922 (or even in 1919-see Reinwald, 1928; Spencer, 1938; Aaloe, 1963; Raukas and Stankowski, 2011; Plado, 2012). Furthermore, Kaljuvee has been recently presented as a forerunner of impact explanation of the famous Ries structure in Bavaria by Martina Kölbl-Ebert (2015). Reinwald (earlier Reinwaldt) was also an outstanding investigator of the Kaali crater field, where he found meteoritic iron splinters, giving the final proof of the first recorded European meteorite crater.

In addition, our analysis of Kaljuvee's opus magnum of 1933 (Major Problems in Geology; in German) exposes some overlooked general notions, in several aspects in good agreement with the conceptual reference to primary LaplaceCuvier-Élie de Beaumont catastrophic notions, so marginalized in the early 20 th century. Therefore, aims of the present contribution are threefold: (1) to broadly outline the historicalbiographical setting of Kaljuvee's and Reinwald's research and their pioneer concepts on the Estonian impact crater site, (2) to summarize and partly correct opinions on their contribution to knowledge of European meteoritic structures, and (3) to present for the first time the original (although partly obsolete) Kaljuvee's 1933 views on principal issues of the Earth history in its planetary setting. We eventually provide English translations of the key excerpts of Kaljuvee's dissertation, as Supplementary Material.

\section{Discovery of Kaali crater in 1827}

The Estonian impact record belongs to unique natural sites, and, owing to good preservation and exposure of the Holocene craters, was the first studied and recognized in detail in Europe. In fact, this was the only scientifically proven meteorite scar on the continent, being commonly accepted as such till $1960 \mathrm{~s}$ (Hinks, 1933; Krinov, 1960; anonymous, 1960), i.e. before the discovery of the similarly sized and also Holocene Morasko crater set in Poland in 1964 (Pokrzywnicki, 1964). The 


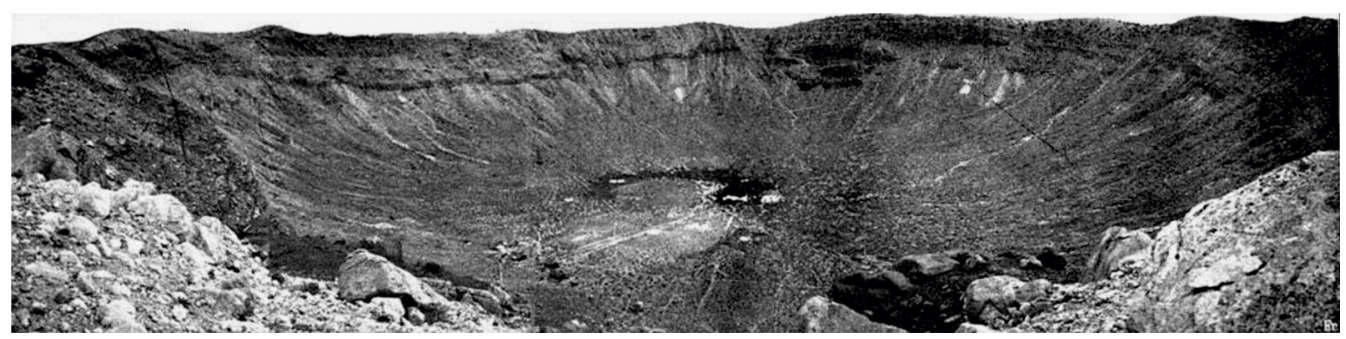

Fig. 1. One of the first photographs of the mysterious crater-like depression in central Arizona (=the famous Meteor or Barringer Crater nowadays) in European journals, provided by German geographer Joseph Partsch (1913, his fig. 22). The interior of crater, which is of $1.2 \mathrm{~km}$ diameter and ca. $180 \mathrm{~m}$ deep, is perfectly shown, and presents also the white spots where wells were drilled (see Barringer, 1905; Merrill, 1908). The Partsch extensive report from the international Transcontinental Excursion in 1912 resulted in wide spreading of the terrestrial impact problems in subsequent papers.

Table 1. Potential terrestrial impact structures, proposed in literature before Kaljuvee's and Reinwald's works.

\begin{tabular}{lll}
\hline $\begin{array}{l}\text { Author and year of the proposal } \\
\text { [selected supporting literature] }\end{array}$ & Geographic location & Comment
\end{tabular}

Halley $(\mathbf{1 7 2 4}$, p. 122;

presented orally in 1694)

Gruithuisen (1844, 1845)

Meydenbauer (1890)

Werner (1904)

Barringer (1905) and Tilghman (1905)

[Munk (1905), Fairchild (1907),

Merrill (1908), Barringer, 1909]

Meydenbauer (1906)

Meydenbauer (1906)

Högbom (1910)

Kalkun-Kaljuvee (1922, 1933;

orally in Kaljuvee, 1919),

Reinvaldt-Reinwald (1928, 1940),

Kraus et al. (1928)

[Ingalls (1928), Kranz (1937)]
Caspian Sea (and other great lake basins)

Aleutian Islands, Kuril Islands, Bohemia, Japanese Islands - Korea, Australia, Sunda Islands, Ceylon, Galapagos Islands; Cape Mt, South Africa

Aleutian Islands, Lesser Antilles; northern Coast Mts, Venezuela; Kuril Islands; Japanese Islands-Korea; Ludschu Islands, China; Mykonos and other Greek islands; Black Sea; Caspian Sea; western Mediterranean Sea; New Guinea, Marianne, Sunda and other Pacific islands; China-Tibet boundary region Ries Basin a Bavaria, Germany

Coon Butte (or Canyon Diablo crater) ${ }^{\mathrm{a}}$, Arizona, USA

Ries Basin ${ }^{\text {a }}$ N Neuwieder Basin, Koblenz; Westerwald, Höhr-Grenzhausen; Bolesławiec (Bunzlau), Silesia; Trzebnickie Hills (Katzengebirge), Silesia Prieska, Northern Cape Province, South Africa (also presumably e.g., Deccan Traps)

Mien and Dellen lakes ${ }^{\mathrm{a}}$, Sweden

Kaali lake ${ }^{\mathrm{a}}$; Estonian island of Saaremaa [Ries crater $^{\mathrm{a}}$, and also several other giant impact sites proposed by Kaljuvee, 1933, such as Mediterrean Sea and Hungarian Plain]
Placed in theological-catastrophic setting ("Such a choc [of a comet] may have occasioned that vast depression of the Caspian Sea, and other great lakes in the World")

Based on hypothesis of Kant (1785) and Élie de Beaumont (1831) who suggested a similarity of Bohemia and Ceylon, respectively, to lunar circular/mountain volcanic structures ("ring-mountain arcs") Approach similar to Gruithuisen's, but without credit to him

Guided by the similarity to lunar craters ("cannot fend off the impression that the catastrophe broke into the area suddenly and as if from outside"; see Kölbl-Ebert 2015, p. 28)

Missing volcanism; rich meteoritic iron around the crater; highly disturbed and crushed rocks in the crater rim, and undisturbed succession in the substratum Disturbed succession of reference lithostratigraphical units (white clays, biosiliceous rocks)

Reference to Meteor Crater and lava floods triggered by cosmic collisions on the Moon surface

Overall reference to Meteor Crater in abstract only

In-depth discussion referenced to Meteor Crater in 1928 and 1933 papers

Year of the first proposal is bolded.

${ }^{a}$ proved later as real impact structure. 


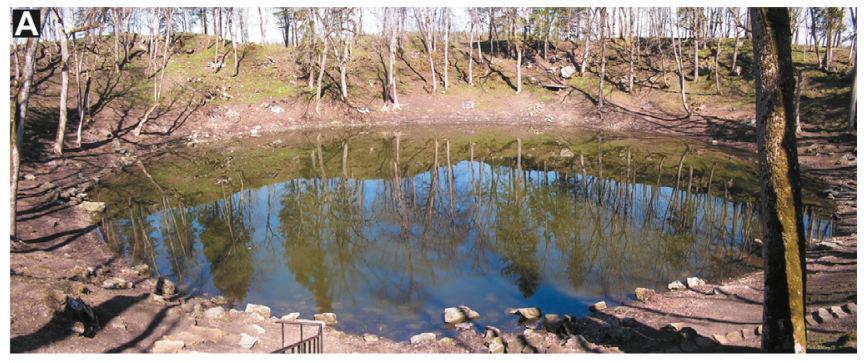

B

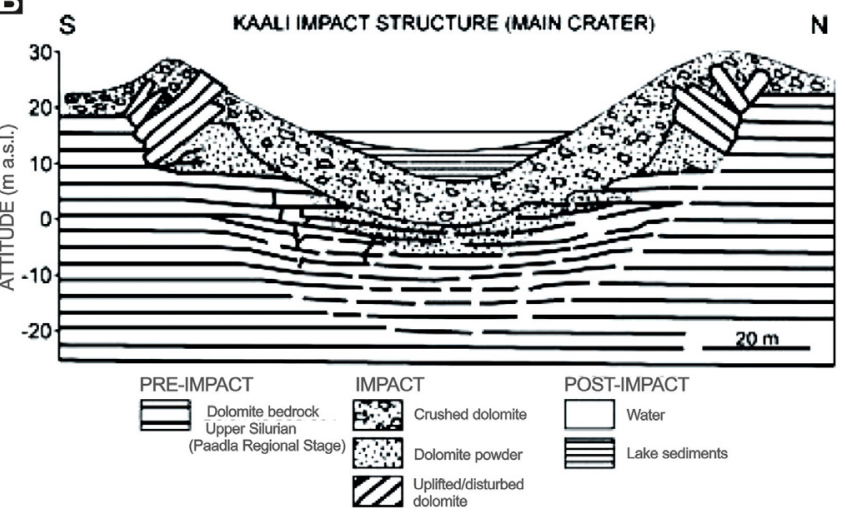

Fig. 2. View of the Kaali lake crater on the Estonian island of Oesel (A; photo courtesy of Reet Tiirmaa), and geological cross-section of the impact structure (after Tiirmaa, 1994, from Plado, 2012, fig. 8).

development of opinions on Kaali crater origin was reviewed by Reinwald (1928), Kraus et al. (1928), Aaloe (1963), Tiirmaa and Czegka (1996), Raukas et al. (2005) and KölblEbert (2015; see also Chirvinskiy, 1931; Spencer, 1933, 1938; Plado, 2012, among others). Only selected questions and supplementary issues are outlined in the introductory chapters.

Nine circular depressions (from 8.5 to $110 \mathrm{~m}$ in diameter) on the Baltic island of Oesel called the attention of scientists for nearly 200 years, and their outstanding cognitive challenge was immediately understood. The Kaali Lake was reported in the early publications in German under name Sall or Gute(s) Sall (property of the Landrath von Gùldenstubbe; Hofmann, 1841).

As usually stated in literature, the largest one, Kaali Lake, had been first recorded in litteris in 1827 by Johann Wilhelm Ludwig von Luce (Fig. 3), a renowned regional historian and naturalist, medic and writer. This clergyman, although born in Germany, after studies in Göttingen and Helmstedt universities, spent most of his life in Estonia, being specifically attracted to the Oesel Island. He is well-known today as an "estophiler" ("estofile"), extensively involved in didactic activity in the national Estonian language. The credit for Luce is evidently acknowledged in the subsequent papers on the Estonian craters in the 19th century. Luce was familiar with the natural curiosity as early as in 1780 when he was mapping this area (Luce, 1827, 1850). While describing the Kaali depression, Luce recognized accurately the crater topography (Fig. 3): "The crater consists of a several fathoms high round hill that surrounds a lake with backwater. On the south side the hill is steeper outside (of the crater), steep inside and surrounded by deciduous forest, and much steeper inside than outside. All the inside gaping mass is located in an oblique upright position. A proof that they have been forced into this

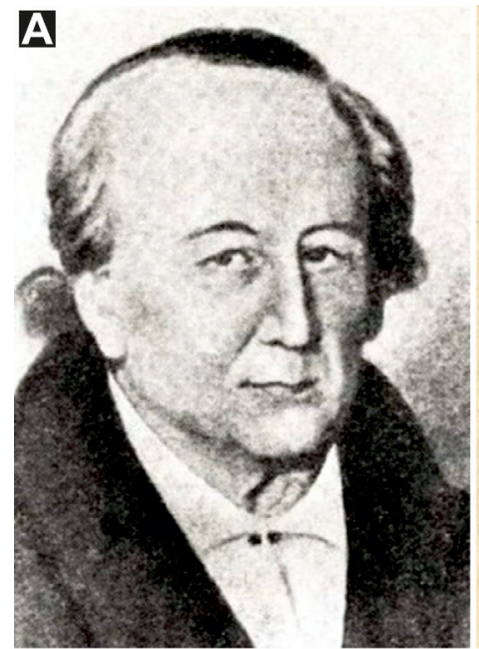

B

Wabrbeit uno Nutbmafung, Bentrag

sur

alteften osefdidite Det Jaler Defel, von

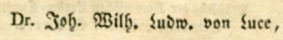
mefrecer gelegrten Befedlífaften mitgliese.

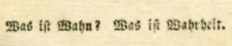
2) 8 x ก เ Gebudt bet gottbacot maraua:ot 1827 .

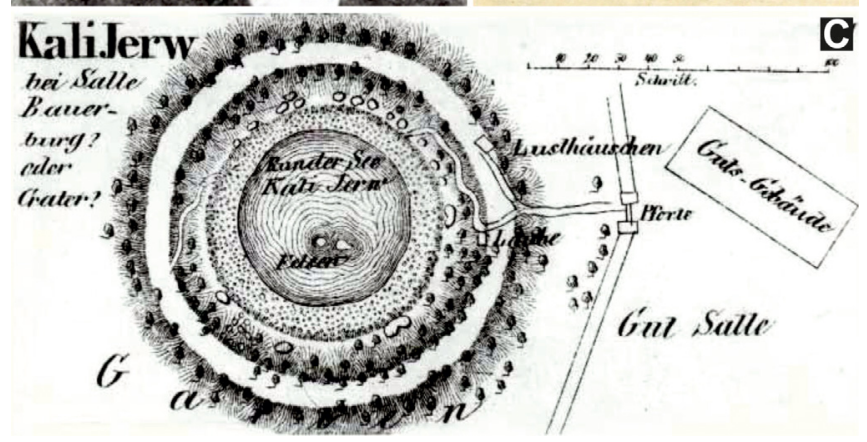

Fig. 3. A. Johann Wilhelm Ludwig von Luce (1750-1842), the German priest and scholar, engaged in propagation of Estonian language, who first described the Kaali lake crater in 1827 (https:// utlib.ut.ee/eeva/index.php?lang=de\&do=autor_pilt\&aid=85\&eid= 37). B. Title page of his work on the Oesel Island, containing first account on the crateriform structure. C. The oldest location plan of the Kaalijärv crateriform structure published in an archaeological monograph of Kruse (1842, pl. 62), who probably introduced this name (as KaliJerw) to scientific literature (Wangenheim von Qualen, 1849 , p. 36).

position from the bottom to the top and from the inside to the outside. In the region, which is very flat, on the surface, there are large flat stones, quite similar to those in the crater, which are apparently ejected from the crater" (Luce, 1827, p. 20; translated from German).

Concerning the crater formation, Luce rationally speculated that "it is unlikely that the island should be lifted from the bottom of the sea by a fiery eruption: although the crater is close to the dwelling-place of the Sall manor, it shows that a fire explosion is not impossible... Something quite similar I saw in 1775 to 1781 in the Hanoverian territory ['handvrischen'] that an explosion of underground fire at the foot of the Külfberg, produced more than 100 feet deep hole which within 5 years filled up from below imperceptibly so that no trace of the former depression remained. The explosion happened without a harbinger, no earthquake, a lightning bolt, and a thunder-like bang were all: there were also no traces of lava or the like. This was a unique explosion of underground fire without further consequences" (Luce, 1827, p. 21; see also Wangenheim von Qualen, 1849, p. 35; Luce, 1850, p. 459). 
Consequently, Luce was already well aware that volcanic explosive forces ("Explosion eines unterirdischen Feuers" in his words) are the only known sufficiently violent geological factor interpretable in the case of observed Kaali crater features. In addition, he put forward a special type of igneous event, without expelled lava. Such an explanation was well reasoned at that time, in the setting of geology, and specifically volcanology, its newly emerging branch (see Sigurdsson, 1999, for review).

\section{Early hypotheses}

\subsection{Volcanic/explosive crater}

Another Baltic German academician, Ernst Reinhold von Hofmann (1801-1871), professor of mineralogy at Kiev University (https://et.wikipedia.org/wiki/Ernst_Hofmann), explored the Oesel area during his geognostic travel in 1837 . He investigated the geological structure of Kaali Lake basin in more detail, without references to conclusion of Luce. He mentioned merely that "the wall-like surroundings consists mostly of limestone layers which are not in their original horizontal position but lifted so that around the pond they stand at an angle $40^{\circ}$ outward. They show clearly that they have been lifted by a force applied at one point upwards and which gave the layers such an outward tilt. In addition to this tilt these layers differ from the limestones on the level ground by their thickness of half foot. These are at some places very jagged and at other places fixed, everywhere with fine-grain and glittering... Since they did not notably foam by dabbing with acid, I believed them to be dolomite" (Hofmann, 1841, p. 140; translated from German).

Therefore, we cannot agree with the recent opinion of Raukas et al. (2005, pp. 343-344) and Raukas and Stankowski (2011, p. 38) that Hofmann (1841) was the first proponent of the "theory" that "the Kaali depression bore an astonishing resemblance to maars-volcanic funnels on the Eifel plateau", and it originated in effect of "an abrupt eruption of water, steam, gas and mud". As shown earlier by Reinwald (1928), the fame of "the smoking gun" discovery in case of the Estonian crater should be attributed to Friedrich August Theodor Wangenheim von Qualen (1791-1864). He was an educated officer ("Major und Ritter"), geologist and Livonian landowner, better known as a manager of Uralian copper mines and explorer of Permian vertebrate sites, collaborating in 1840s with Roderick Murchison, the famous English geologist (Palmer, 2005, p. 154). Von Qualen published his results in three notes in Riga and Moscow (Wangenheim von Qualen, 1849, 1850, 1852). Concerning the origin of the bowl-like depression, he decisively emphasized: "After all what I have said here about this crater is its similarity to the old craters or to the so-called maars or mofettes in Eifel on the left bank of Rhine, in Bohemia and in Auvergne, as it is described by Élie de Beaumont in 'Geologie und Petrefaktenkunde', by D. Voigt, 3rd delivery in 1847, and by Dr. C.F. Naumann in 'Lehrbuch der Geognosie', Leipzig 1849; especially this similarity stands out in the case of maars at Lacher-See and at Weinfelder near Dann" (Wangenheim von Qualen, 1849, p. 61; translated from German).

These results of refined study by an experienced geologist, illustrated by impressive cross-section and plan (Fig. 4A), were indeed outstanding for the next 70 years (see Holzmayer, 1880), and in line with the accepted views on the famous Ries crater till 1960s (Kölbl-Ebert, 2015; see below).

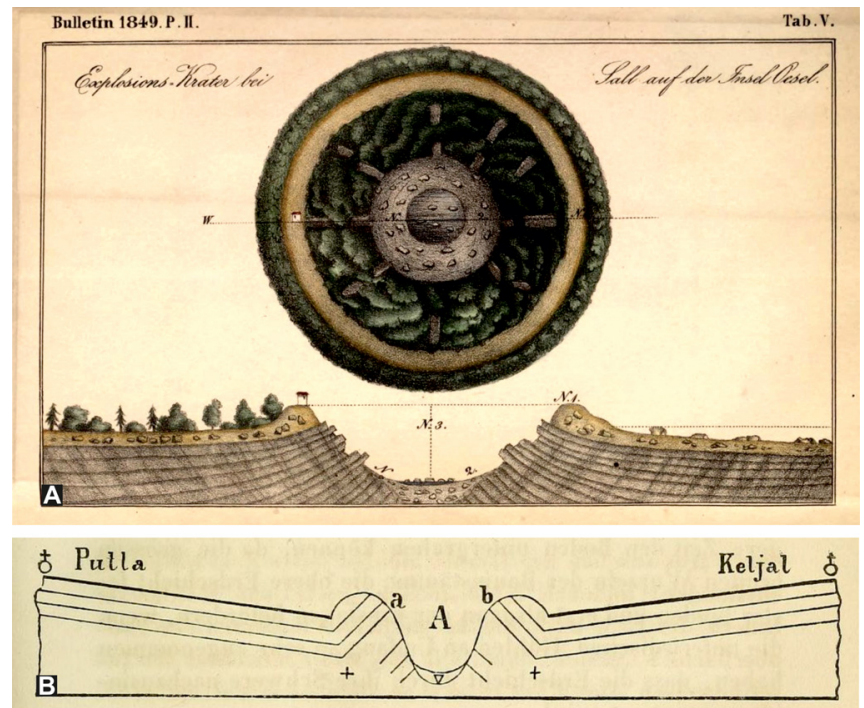

Fig. 4. First geological cross sections and schematic plan of the Kaalijärv crateriform structure, published by Wangenheim von Qualen (1849, pl. 5 in the Moscow edition; A) and Eichwald (1854, p. 8 ; B1), as a visualization of two opposing endogenic models, maartype volcanic and sinkhole, respectively (compare with later graphical elucidation of the crater as the meteorite impact site-Figs. 2B and $5 \mathrm{C}, \mathrm{D})$. In the hypothesized ground collapse, "A" means a funnel-like depression, "+" - the layers of limestone at the lake are subsided, they are strongly bent and broken and they show the layers at the wall "a" from it downfallen position, almost as at "b" where "+" means that there has been similar downwashing of clay layers between the limestone layers. It shows directly that there is a subterranean connection between the lake and the spring at Salla.

The paper of 1919 by Otto von Linslow (1872-1929), the Professor of Geology in a survey department on the northeastern front (as military geologist; "Kriegsgeologe") in Kowno in 1917-1918, was a next step in this conceptual route. Basing on borehole data, he offered the novel scenario of an explosion of methane, derived from chemical self-decomposition of organic matter (the phenomenon reported from the region; see Chirvinskiy, 1931). Linslow (1919) hypothesized that the Ordovician bituminous shales (with Dictyonema), occurring below the crateriform structure, represent the earth gas source for the sudden blast episode ( $c f$. also Andrée, 1929 in Reinwald, 1938b). A subsequent German contribution, by Curt Teichert, in that time probably a doctorate student of geology at Albertus University in Königsberg (in future, the eminent Australian-American palaeontologist), resulted from a brief field survey in summer 1926 (guided by Artur Luha; see below). After thorough consideration of the Linslow hypothesis, Teichert accepted the traditional conception, according to which "the crater of Sall represents typical maar" (although without quoting older papers).

\subsection{Collapse crater and other non-volcanic hypotheses}

Several explorers of the Oesel region in the second half of 19 th century proposed non-explosive origin for the craters. The 
sometimes opposing hypotheses (e.g., in Eichwald, 1854), accounted exhaustively by Reinwald (1928), include ground collapse due to karst processes in fissured carbonate substratum (Fig. 4B), or - conversely - water absorption and swelling of underlying clay series (Eichwald, 1854, pp. 77-83; Schmidt, 1858, pp. 86-89). On the other hand, surprisingly also artificial, anthropogenic transformation of the lake surroundings was alleged, owing to building of an ancient stronghold (e.g., Eichwald, 1854, pp. 78-79).

Even within the German group surveying the Kaali crater field in 1927 (Kraus et al., 1928), the first co-author proposed individually "Dolinenhypothese", i.e., that the lake basin resulted from the collapse of swelling evaporite-dome mobilized by ice during Pleistocene glaciation ("sinkhole called actually cone-or bowl-shaped depressions in karst area"; see Kölbl-Ebert 2015, pp. 116-117). Interestingly, similar idea was accepted earlier by the director of the Estonian Department of Mines, Jaan Kark (1876-1953). He was a mining engineer and geologist, graduated at St-Petersburg Mining Institute in 1907, active in Caucasus and Central Asia, and in later times a lecturer at University of Tartu and professor of applied geology at Tallinn University of Technology. The halokinetic hypothesis of Kark was indeed a starting point to extensive prospecting for salt and gypsum by Reinwald in Kaali lake area, by order of the Estonian government (Tiirmaa and Czegka, 1996). This concept based on the known salt occurrence in the Silurian succession of Saaremaa. It was briefly revitalized by Chirvinskiy (1931), and also by Andrée (1932) whose magnetic research failed to discover iron buried in the Kaali crater, thus strangely repeating the misleading Gilbert's (1896) magnetic test in Meteor Crater (Hoyt, 1987).

\subsection{Summary}

Summarizing all the pioneer attempts to ascertain the origin of the mysterious Estonian crateriform structure, varieties of endogenic (or cryptovolcanic) explosion and sinkhole models persisted well in the time of early Julius Kaljuvee scientific activity. A somewhat similar cognitive stage in discussions on explosive cratering processes had existed in the case of Meteor Crater since Gilbert (1896; Keyes, 1907), at least in judgment of large part of the geoscientific community.

The interpretation of other European impact structures likewise evolved from the volcanic one in 18th and 19th centuries to an undoubted meteorite scar in 1960s, perfectly exemplified by the Bavarian Ries crater (see below). A matching recognition route may also be demonstrated for the eroded Rochechouart structure, France, $23 \mathrm{~km}$ in size (see a historical review in Kraut, 1969).

\section{Meteoritic hypothesis}

\subsection{First European impact studies}

In continental Europe, sensational news on diamondbearing Canyon Diablo meteorite, combined with "the most interesting feature on surface of our planet" (in words of the famous Swedish chemist, Svante Arrhenius, referring to the Arizona crater; after Hoyt, 1987, p. 171), were immediately picked up and variously interpreted (e.g., Mallard and Daubrée, 1892; Lapparent, 1897; Meyer, 1902). Following the impressive publications on meteorite impact scenario by Barringer (1905, 1909), Tilghman (1905), Munk (1905), Fairchild (1907), and especially by Merrill (1908), as well as the countless supporting articles in scientific magazines (Nature, Science), popular-science periodicals (Scientific American; National Geographic, La Nature) and even in well-read newspapers (e.g., New York Times, Evening Star, Washington Post), more or less detailed accounts on the astonishing theme were published in various European languages (anonymous, 1908, 1912a; Günther, 1911; Sjögren, 1911, among others; see summary in Racki et al., 2018). Particularly well-illustrated popular-science article by Meinecke in Naturwissenschaftliche Wochenschrift (1909) was a foremost impulse in the spreading of impact idea not only within the German-speaking countries (e.g., Rydzewski, 1910). Even a very original but overlooked idea of explosive nature of the Canyon Diablo impact was proposed in the Netherlands in this time (Mulder, 1911; see Racki et al., 2018). The search for possible bolide scars on the Earth was intensified in that time (Tab. 1), paired with concepts of cosmic explosion collisions, and a gradual shift in volcanism $v s$. meteorite debate on origin of lunar craters toward the second hypothesis (see Hoyt, 1987; Racki et al., 2014, 2018).

The noteworthy publication acme followed the international Transcontinental Excursion, organized in 1912 by the American Geographical Society (Fig. 1), when stimulating queries about the Meteor Crater were widely debated in European societies (e.g., Bergeron, 1913; Calciati, 1913; Margerie, 1913; Partsch, 1913; Olufsen, 1914). Nevertheless, the European mainstream geoscience invariably applied the uniformitarian-gradualistic Lyellian approach to the Earth history, and endogenic phenomena, observed only recently ("before our own eyes"), were highly preferred in the interpretation of enigmatic circular depressions on Earth's surface (see Hoyt, 1987; Kolchinsky, 2002; Palmer, 2003; Kölbl-Ebert, 2015).

\subsection{Meteoritic hypothesis of Kaljuvee (1919-1933)}

Two Estonian geoscientists, with a somewhat different curricula vitae, who lived simultaneously in the late nineteenth/early twentieth centuries (but likely never have collaborated), complementarily contributed to the successful recognition of Kaali crater field (Fig. 2).

\subsubsection{Julius Osvald Jaan Kaljuvee (Kalkun) - life and scientific activity}

Julius Osvald Jaan Kalkun (after 1928 Kaljuvee; Fig. 5) was born on July 9th (on June 27th according to the Julian calendar) 1869 in Saru parish, Võru county, in the south of Estonia, as the eldest son of a schoolteacher's big family. Julius was graduated from the Võru district school and obtained a primary school teacher profession in 1886 . He worked as a teacher in Koigi and Rebaste primary schools during 18891897, in St. John's parish school (1998-1900, 1903-1906) in St. Petersburg, as an accountant at Onega town (1901-1903), and as a teacher in the School of Commerce of the St. 


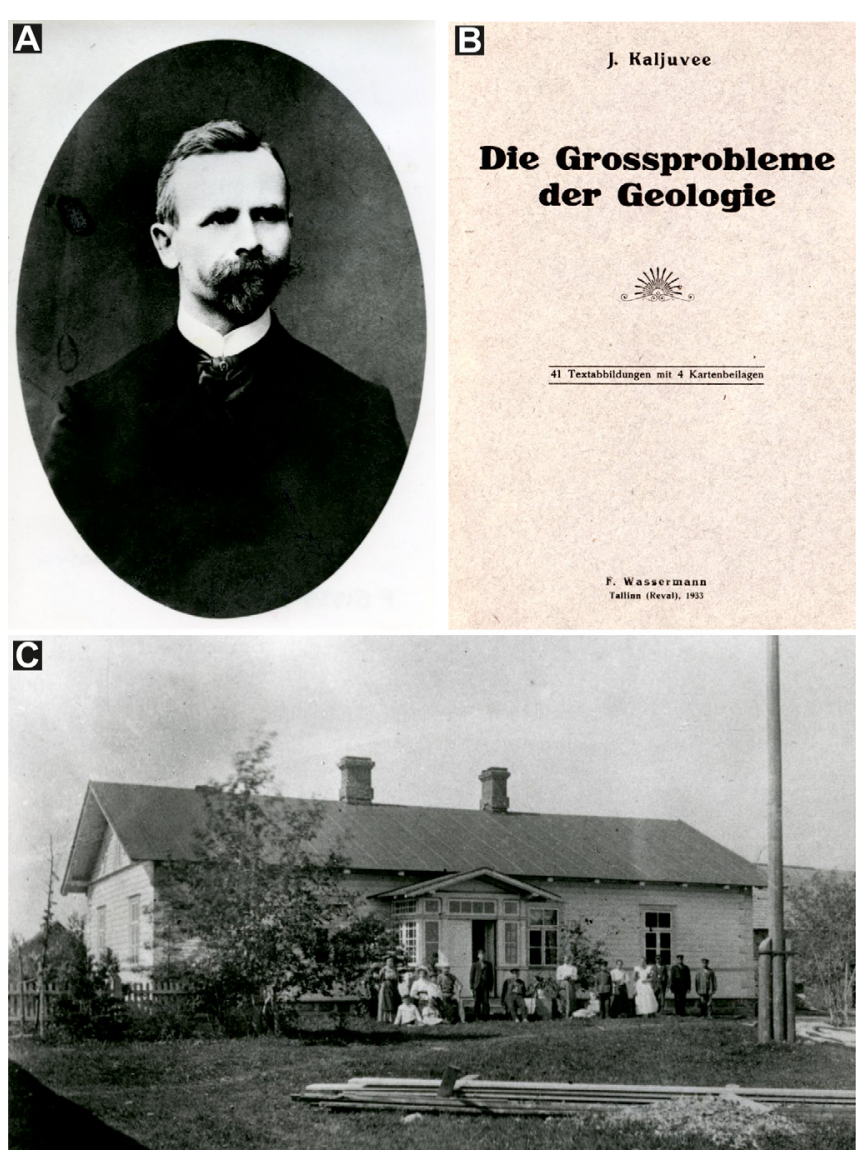

Fig. 5. A. Julius Osvald Jaan Kalkun, since 1928 Kaljuvee (18691940), before 1917. B. Title page of his major contribution to geosciences. C. Saru Parish School (Mõniste parish near Võru), where he was elementarily educated. Courtesy of the Archive Museum of the Estonian Pedagogics, Tallinn University (A and C).

Petersburg Imperial Philanthropy Society (1906-1907). In 1906 he passed the vocational exam for the German language tutor and in 1907 he came back to Estonia, where he worked as a teacher in the Tallinn Jacob's school during the years 1907-1909, and as the first headmaster of the public school of the Viru-Jaagupi Education Society in 1907-1909 (the school was designed by himself). Between 1910 and 1915, he worked as a teacher in the Jaan Kirsipuu public gymnasium in Tallinn. At that time, he published his textbook The Mineralogist's Manual and became a professional teacher of the natural history in the Tallinn St. Peter's Secondary Science School in 1914. He continued to work as a teacher in the Tallinn higher primary school in 1915-1917. In the years 1919-1931, he worked as a teacher of natural history and physics in the Tallinn Teachers' Seminary. In 1928, Julius Kalkun changed his surname to Kaljuvee ("Kalkun" means "turkey" in Estonian) and under this name he is known in reference books. On July 9th, 1939 he celebrated his 70th birthday as a recognized teacher. In 1940, he died and was buried in the cemetery of Viru-Jaagupi.

Looking back to his life, one may say that he started his work as a schoolteacher in the time of severe russification of the Baltic provinces - the pupils were not allowed to speak their mother tongue in schools. In these hard times, Julius Kaljuvee coined many terms of natural sciences in Estonian language. However, funny they may feel for the Estonians nowadays, Julius Kaljuvee was one of the many founders of the Estonian scientific language in the times when even the Estonian literary language was still in statu nascendi. His versatility is proved by the fact that he wrote also poetry (the collection of poems From the alien greens, 1907), brochures and libretti of oratori. Headmaster in Viru-Jaagupi school, he was also a choirmaster there and sang as an honorary member in the Estonian Male Choir.

His first book The Mineralogist's Manual was reprinted in Estonian in 1922, and his interest in geosciences lasted for his whole life. As Julius Kalkun he published in Estonian also the books Natural Training Excursions (1920), General Geology (1922) and translation of Henry Winkler's Geology of Estonia. Kaljuvee's main publication is the comprehensive discourse Die Grossprobleme der Geologie. Hinweise zur lagenden Lösung (Major Problems in Geology. The Solution which is Waiting), completed in 1931 and published in 1933 in Tallinn (Kaljuvee, 1933). Several novel-provocative and in part highly controversial ideas from this book are reviewed below.

Kaljuvee's special role in the geological education and science of Estonia evolved on the basis of his exceptionally wide knowledge of the historical and regional geology and related sciences. On the other hand, he was merely a self-taught individual who had no systematic geological education and lacked opportunity to discuss with colleagues. Although we do not know much about his field research (also exemplified by Kaali craters), photographs in his books indicate Kaljuvee's own observations of Estonian nature. Thus, his main activity was at length analysis and compilation of literary or oral data, but he markedly placed the descriptions of Estonian phenomena into the context of neighboring countries, of Northern Europe or the northern hemisphere, into global, sometimes even cosmic, context. He was strikingly familiar with current foreign literature (see below). Having so broad intellectual horizons and sufficient knowledge resource, Kaljuvee, despite an essentially amateur status, gained a researcher reputation both at home and abroad.

\subsubsection{Intuitive impact conception}

The proliferation of attractive geoscientific concepts in the first decades of 20th century certainly affected the thoughts of Julius Kaljuvee (Kalkun in those days) on the mysterious Kaalijärv crater-like structures, as he doubted the previously proposed models by Eichwald, Schmidt, Linstov, etc. (Kaljuvee, 1933, p. 102). Since 1914, he was an ardent admirer of Alfred Wegener's dynamic Earth theory (Wegener, 1912). Thus, Kölbl-Ebert (2015, p. 29) suggests a direct influence also of Wegener's impact experiments that resulted in notable imitations of lunar craters (Wegener, 1921; noted in Kaljuvee, 1933, p. 100). However, he did not specify concrete external sources for such an inspiration. Furthermore, as explained in Grossprobleme der Geologie:

"Until the middle of the last years of the war, the existence of this crater was known to the author [i.e., 
Kaljuvee] only from reports by eyewitnesses. In August 1911, for example, the teacher of natural sciences and mathematics J. Sarv, at the Estonian Girls' Gymnasium, now professor at the University of Tartu (Dorpat), returning from the summer vacancies in Kuressaare, told so many interesting facts of the crater to the author. He answered my question, whether it was really an extinct volcano with tuffs and lava, by the negative, because volcanic ash or lava were nowhere to be seen... in the course of a lecture in November 1913, a resident of Saaremaa, who was amongst the listeners, raised a question about the elucidation of the riddle of the Kaalijärv. At first, I let respective eyewitnesses and questioner who had grown up on the spot briefly refer all they knew about the crater, almost all the morphological characteristics of the crater known to date, stimulating the conversation with relevant questions. Unaffected by the already existing explanation attempts of the crater of the Kaalijärv, but only as a result of intuitive illumination, the judgment escaped me: it is the site of fall of a gigantic meteorite! Finally, the renewed efforts brought me to the long-awaited literature on the crater of the Kaalijärv, and with it also the disappointment of not finding my opinion in it. After a further consideration of the whole situation, I finally turned categorically to my own point of view... In 1919, I was appointed as scientific lecturer of the first Estonian teachers' seminar. During the first general Estonian Teaching Congress, I gave a special report for interested colleagues from the first ideas of a new solution to the ice age problem, which was not yet developed at that time, where my view of the formation of the crater of the Kaalijärv by meteorite impact also played a role" (Kaljuvee, 1933, pp. 102-103).

So, from the explanation it is clear that the innovative Estonian application of impact idea was indeed an independent intellectual achievement, first expressed during the public lecture as early as 1919. In 1922, however, the important remark was published by Kaljuvee in the textbook for Estonian schools, Üldine Geoloogia (General geology), as a footnote on page 101: "I dare to consider the Kaali lake in Saaremaa a meteor impact which has given cause for various debates". This laconic mention had a heuristic valor very soon, as intensive works started in the Kaali Lake area five years later, under supervision of Reinwald (see below; Fig. 6). Remarkably, Kaljuvee was for Reinwald a conceptual father of impact scenario, in this particular Estonian case (as cited in Reinwald, 1928, p. 33).

The Kaljuvee's views on impacts and Kaali crater field were comprehensively advanced in the chapter 3 of his 1933 book (Kaljuvee, 1933; summarized by Kölbl-Ebert, 2015, pp. 29-32). He reviewed a rich literature on the subject, and analyzed all five presumed meteorite craters known at the time, as well as the Tunguska event, in the context of Estonian craters. He quoted American papers by Merrill (1908) and Magie (1910), and when making comparisons with the reference Meteor Crater, stressed a close morphological similarity of both structures despite the difference in size and the lack of extraterrestrial remains in the Estonian case. Kaljuvee explained this discrepancy in part by anthropogenic modification, i.e. man-made removal of ejected material. However, he speculated further that "it certainly suffices to say that the fall of a meteorite on the surface of the Earth is accompanied by a manifestation of explosion. It is also clear that this is not always the case. We will also have the opportunity to report such cases. A total destruction of the meteorite mass by sudden deceleration of the movement and explosive action of the vapors of water can, by the way, occur only in smaller meteorites. The larger meteorites are likely to remain almost intact, even when they fall into the ocean. It would also be conceivable that, in the case of a water vapor explosion, the relevant meteorite rebounds on the extremely elastic vapors and falls again at a great distance. It is by no means impossible to conceive that, for example, the meteorites of the Kaalijärv bounced off in such a way, and lies perhaps somewhere in the vicinity of Saaremaa, under the Baltic Sea. When assuming a sufficient iron content of designated meteorites it would be possible to determine their presence in connection with the numerous magnetic anomalies of the Baltic Sea in the vicinity of Saaremaa" (Kaljuvee, 1933, pp. 107-108).

Of course, this justification is inaccurate in physical terms, because the destructive shocks are evidently overall proportional to the size of falling bolide. As stressed by Kölbl-Ebert (2015, pp. 118-120), the proposed process was flawed due to omission of the kinetic energy release of the striking cosmic projectile, like in many other studies before Kaljuvee (Hoyt 1987, pp. 314-317; Racki et al., 2014, 2018). With regard to the cratering mechanism, Kaljuvee (1933, p. 105) regarded the cosmic hypervelocity (50 to $70 \mathrm{~km} / \mathrm{s}$ ) as the principal character of the impact event. He followed, however, a confusing idea of Reinwald (1928) that excavating effect of the shock waves was significantly augmented by forceful explosion of steam when the penetrating mass contacted with groundwater (in fact repeating the scenario of Merrill, 1908, for Meteor Crater).

\subsection{Discovery of the Kaali crater field by Reinwald (1927-1938)}

4.3.1 Ivan A. Reinwald (Reinwaldt) - life and scientific activity

Ivan Aleksandrovich Reinwald (or Reinvald; till 1935 written as Reinwaldt; Figs. 7A, B and 8A) was born on May 8th, 1878 in a workers' family in St Petersburg. He received higher education in Moscow and St Petersburg. In 1898, he started studying in St Petersburg Mining Institute. Ivan was many times expelled from the institute for students' disturbances, so he graduated from the Institute only in 1907 as a mining engineer. Up to 1912, he remained the curator of the St Petersburg Mining Institute Museum of Geology. During the First World War (1914-1917), he served in the medical service of the Russian army. After the war, Reinwald returned to his specialty and came back in 1921 to his father's homeland - Estonia - which has just become independent. $\mathrm{He}$ started to work in the Mining Department of the then Ministry of Trade and Industry, as a mining inspector. He remained in this charge until his demise on April 30th 1941 in Tallinn.

Ivan Reinwald started his professional activity in 1913 in Turkestan, investigating the deposits of copper ore and coal. During the years 1917-1921, he took part in organizing different scientific institutions in St Petersburg (then Petrograd) and in their work. In Tallinn, he first investigated the deposits of blue clay on the Kopli Peninsula and the deposits of 

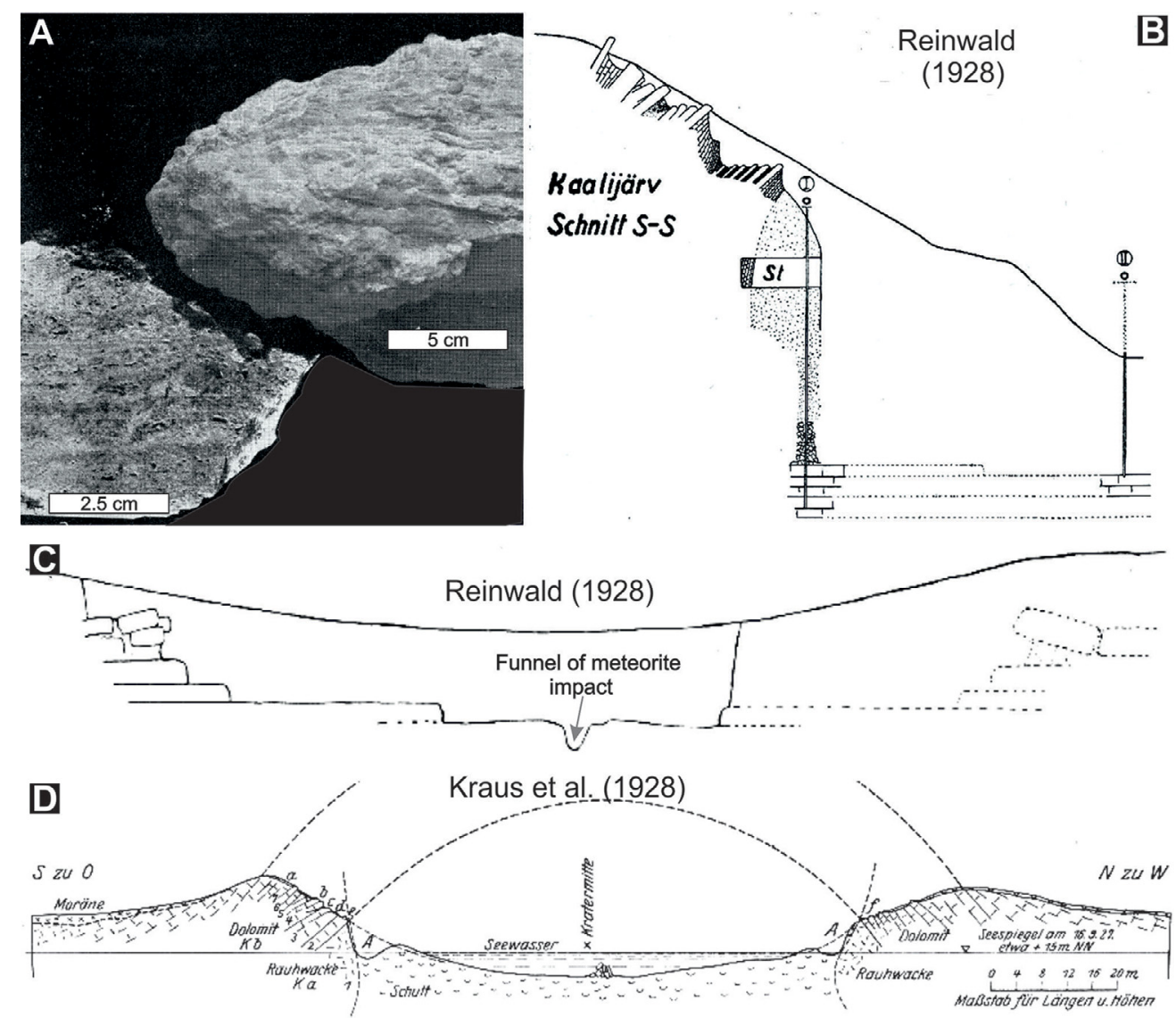

Fig. 6. Illustrated results of extensive field works in autumn 1927 in the Kaali lake area by Reinwald (1928; A-plate 3:1; B and C-pl. 4, sections S-S and A-B, respectively; see Fig. 6D) and Kraus et al. (1928, fig. 9; D). A. The impact-altered dolomite rock from the borehole core in the bottom of a small crater no. 4 (of $20 \mathrm{~m}$ diameter), as a crude slab (right specimen) and its polished fragment (left specimen). B-C. Profile of excavated rim wall (A) and cross-section of the crater no. 4. Note a supposed funnel of meteorite strike at the bottom of a crater (grey arrow; see Fisher, 1936, p. 299). D. Interpretative cross-section of main Kaali crater showing an alleged scale of the surface transformation by meteorite strike and resulting explosion (A-digs, 1-7 refer to tilted layer numbers).

the lake lime at White Lake in the south of Estonia for private entrepreneurs. Later, he studied the oil shales and their tectonic setting (faulting and folding). In addition, he surveyed also the deposits of glass sand, gypsum, phosphorite, limestone and dolomite, brick and fireproof clay, lake lime and galena. He also took part in hydrological investigations. Despite so extensive professional experience and achievements in regional ore geology and mining, Reinwald got his high reputation mainly by the systematic study of the Kaali craters (Kulik, 1940, Raunet, 1940; Krinov, 1960; Aaloe, 1961, 1963).

\subsubsection{Reinwald contribution}

This amazing but strictly intuitive idea of Kaljuvee-Kalkun (1922) on Kaali crateriform structure was in-depth confirmed in 1927, at the occasion of the comprehensive mining-resource search ordered by the Mining Department of the Ministry of Trade. The area had been multiply excavated and drilled to a depth of $63.14 \mathrm{~m}$, what significantly explained its structure and geological setting (Fig. 6).

The search project was fruitfully realized by Ivan Reinwald, with participation of Artur Luha from Tartu University. In addition, the renowned German geoscientist Alfred Wegener,
Professor at the University of Graz, Austria, visited the crater during the autumn of 1927 (see detail in Greene, 2015, p. 540); he was accompanied by geoscience professors from Riga, Ernst K. Kraus and Rudolf Meyer, who contributed to this work (see Tiirmaa and Czegka, 1996; Kölbl-Ebert 2015, pp. 116-120). As noted above, Wegener was an effective empirical supporter of meteoritic theory for lunar craters (Wegener, 1921), and the field examination of real terrestrial craters was probably an impressive happening for him during his five-day visit. Reinwald (1928, p. 33) mentioned him and Kaljuvee as the first advocates of impact origin for the Estonian craters. Unsurprisingly therefore, as stressed later by Kaljuvee (1933, p. 104), the results of the international collective investigation led to "the rejection of all other hypotheses except meteoritic hypothesis".

This conclusion was markedly delineated in two outstanding papers of 1928 (Fig. 6), published in German in Estonia (Reinwald, 1928) and Germany (Kraus and Meyer, 1928; Kraus et al., 1928). In both publications, but particularly in Kraus et al. (1928), a thorough comparative analysis of the Estonian structure with reference to Canyon Diablo crater was presented for the first time outside the United States. The authors accordingly stressed inclined and crushed rock layers at the crater ring (Fig. 6), and the absence of volcanic 
signatures in Estonia. In addition, they discovered that in fact the Kaali group of five related craters is comparable with pitted area caused by the 1908 Tunguska bolide explosion in Siberia, where also no extraterrestrial material had been discovered. Earlier attempts to find meteorite/cometary scars in Europe were very speculative (Tab. 1), and only Arvid Gustaf Högbom (1857-1940), professor of mineralogy and geology at Uppsala University, suggested in 1910 such a possibility for Mien and Dellen lake basins in Sweden, first in comparison to the Meteor Crater. However, Högbom's supposition was presented in abstracted form, in contrast to multi-aspect discussions by Meyer and Wegener (in Kraus et al., 1928) and Reinwald (1928, 1933), reviewed at length by Kaljuvee (1933).

Reinwald (1928) considered cautiously a physical process dynamics of the craters formation by meteorite shower, even if partly erroneously in the light of recent physical knowledge. He analyzed a key significance of the projectile velocities in meteorite fall record, but significantly added: "The specific appearance of the phenomenon is dependent on many individual conditions: 1) on the type of meteorite, 2) on its size and form, 3) on the properties of the rocks that take in the meteorite (their hardness, bedding, water content and so on), 4) on the angle of impact and so on" (Reinwald, 1928, p. 49; after Kölbl-Ebert 2015, p. 119). So comprehensive view of cratering process was indeed novel, because the important role of target substratum was rarely considered in the impact characteristics even in the 21 st century (Racki, 2012b).

On the other hand, the alternative halokinetic model of Kaali crater field of Kraus (see above) was finally disproved by further search of Reinwald in 1937 when he found 30 meteoritic iron splinters, up to $8 \mathrm{~cm}$ in size (Fig. 7C), in two secondary craters (Reinwald, 1938b, 1940). This remarkable finding confirmed the triumph of the Kalkun (Kaljuvee) hypothesis still during his life.

A mysterious matter in the exploration of the Estonian craters was the effective participation of Wegener. As recently explained by Greene (2015, p. 540), shortly after publication of the impressive Wegener work on impact nature of lunar craters (Wegener, 1921), he was repeatedly invited (till 1927) by "an engineer from Riga" to verify a putative impact nature of the Kaali circular depression. He had gained finally a financial support in 1927 to survey the structure, in addition to his joint interests with Johannes Letzmann (1885-1971), an Estonian climatologist and innovative tornado investigator. We can only guess whether the anonymous Latvian engineer was inspired by the concept of Kaljuvee (1922).

Information on the explained Estonian natural curiosity, with conclusive evidence at hand, was widely debated in continental Europe, also in light of the stimulating Kaljuvee's 1933 dissertation (see below). In Germany, for instance, Kranz (1937) compared the Kaali and Ries structures already as impact sites, despite undiscovered meteorite remains in those days (and also regardless of negative results of magnetic survey, Andrée, 1932). He even unnoticed crucial inferences of Kaljuvee (1933). This somewhat odd paper was followed immediately by already conclusive popular-science communication of Reinwald (1938a).

\subsection{American and British promoters}

Surprisingly, the noteworthy publications of Reinwald (1928) and Kraus et al. (1928), applying the impact model to

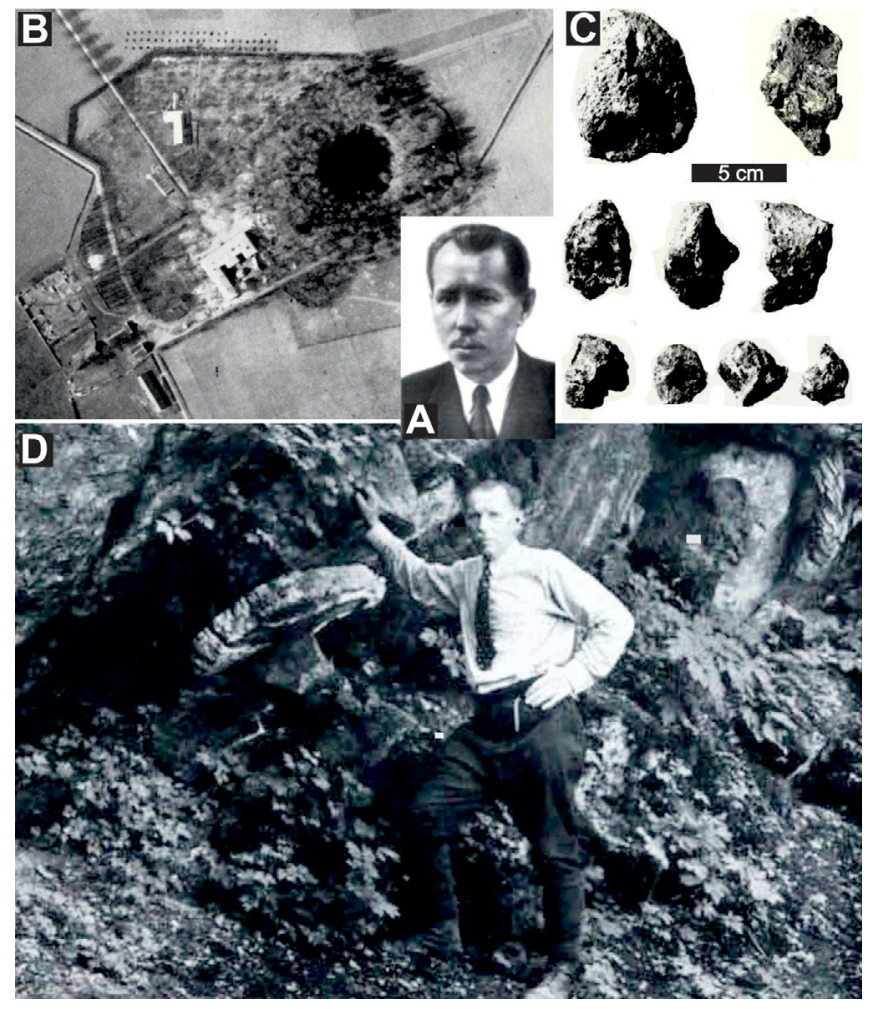

Fig. 7. Ivan A. Reinwald (A; https://www.geni.com/people/IvanReinwald/6000000052529043831), inspector of the Mining Industry of Estonia, leading researcher of the Kaali crater field since 1927, and the principal impact characters documented by him: tilted dolomite strata in the upper part of the interior wall of the Kaali crater ( $c f$. with Fig. 6), with Reinwald in the foreground (B); shattered meteoritic iron pieces from craters no. 2 and $5(\mathrm{C})$, and Kaalijärv viewed from aeroplane of Estonian Air Defense in 1938 (D); from Fisher (1936, p. 298; B) and Reinwald (1940, C-compiled from figs. 10 and 14; D-fig. 5, $c f$. with Fig. 2A).

the Kaali crater field, coincided in time with a similar idea presented overseas, in widely read American popular-science magazine Scientific American. The one-page notice on $A$ miniature Meteor Crater in the July 1928 issue, with two photos and simplified map, was authored by Albert Graham Ingalls (1888-1958), active scientific editor, amateur astronomer and telescope maker. He announced in subtitle that "circular, crater-like depression in Esthonia [sic] bears at least superficial resemblance to the famous crater in Arizona".

Ingalls outlined two acceptable models of the crater formation, sinkhole attributed to karst processes and "meteoric theory", both "mentioned by the well-known geologist, Professor Alfred Wegener". The last hypothesis was distinctly preferred by Ingalls, "at least tentatively", by a clear analogy to Arizona crater, including missing volcanic evidences, tilted up rocks of the crater rim and "deposit of dolomite powder mixed with larger stones".

Estonian sources of Ingall's data are the second surprise. He quoted that "geologists of the University of Dorpat... are endeavoring to discover the mysterious origin of a peculiar geologic feature on the nearby island of Oesel" (concerning 


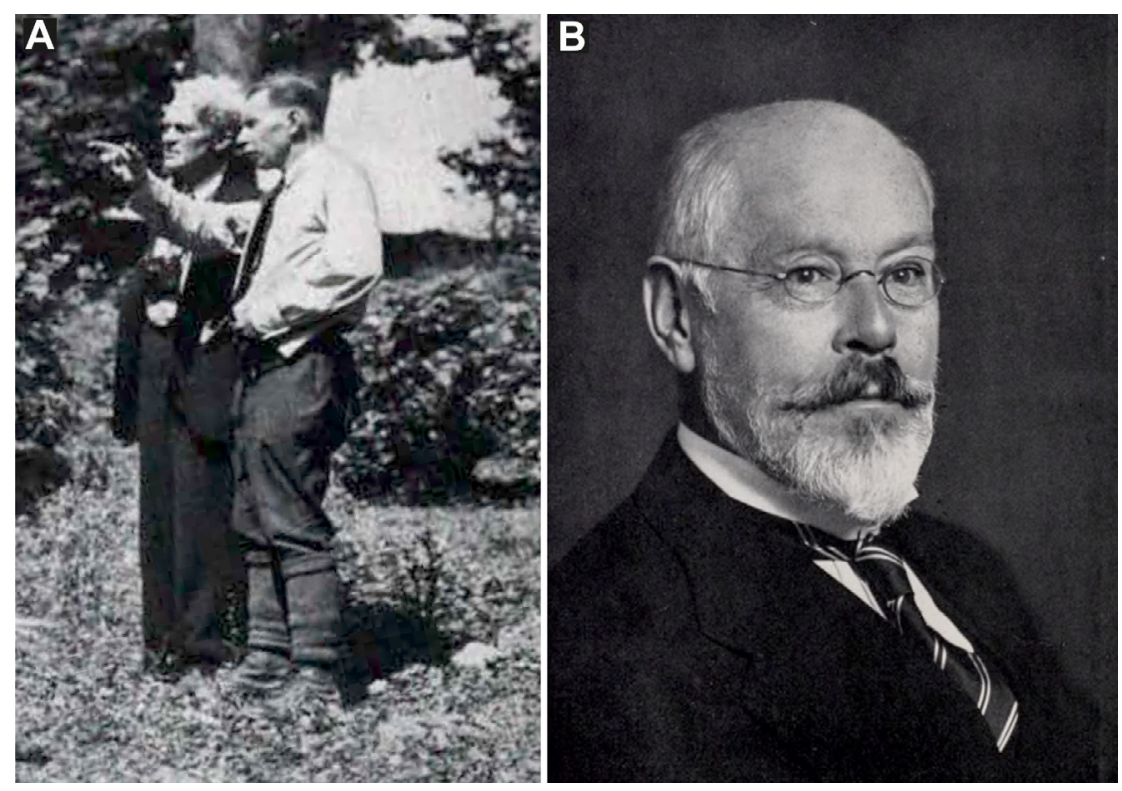

Fig. 8. Propagators of Estonian crater theme in the English-language world. A. Ivan Reinwald (on the right) and Clyde Fisher, active educator and traveler from the American Museum of Natural History (https://en.wikipedia.org/wiki/George_Clyde_Fisher), on the floor of the Kaali crater no. 2 in 1936 (from Reinwald, 1938b). B. Leonard James Spencer (1870-1959), a renowned British mineralogist, Keeper of Minerals in the British Museum Natural History, and Reinwald's collaborator (from Tilley, 1961).

Luha, author of one photograph), as well as specifically noted observations "furnished by Mr. Konstantin Komets of Reval" (Tallinn today). Konstantin Komets (1869-unknown date) was a former Russian businessman, who escaped from the Soviet Union in 1922, and earned his living in Estonia as a teacher of English language and a foreign correspondent of American journals Scientific American and Science and Invention (Loit, 2011). This explains why Americans heard about the Kaali crater from him. The Ingall note distinctly shows that a broad group of people was involved in 1920s in the exploration of Estonian craters.

Leonard James Spencer (Fig. 8B), leading English authority on meteorites, editor of Mineralogical Magazine and Mineralogical Abstracts, successfully propagated the impact crater idea in 1930s (Tilley, 1961; Hoyt, 1987, p. 346). He had already accepted the probable meteoritic origin for Estonian structures (among 10 craters worldwide) in a detailed 1933 review for Geographical Journal, in light of both 1928 papers. Spencer collaborated later with Reinwald in chemical analyses of Estonian meteoritic iron (Spencer, 1938; Reinwald, 1940). He incorrectly noted, however, that Kaljuvee (Kalkun), proposing the impact model in 1922, compared Kaali lake structure directly with the Arizona crater (Spencer, 1933 , p. 233 ; 1938, p. 75 , with quotation of Reinwald, 1928; also repeated by Aaloe, 1963, p. 26).

The promoted interest in British scientific community was so great, that one of the most eminent geographers and astronomer, Arthur Robert Hinks (1873-1945; https://en. wikipedia.org/wiki/Arthur_Robert_Hinks), personally visited the Kaali craters in 1933 under Reinwald's guidance. In a brief account in Geographical Journal, Hinks recapitulated that "the evidence of a tremendous explosion in the principal crater is impressive... and impact of a meteorite the only assignable cause", thus the impact structures are "the only example hitherto recognized in Europe" (Hinks, 1933, p. 375).
In 1930s, the next enthusiast of the Estonian craters was George Clyde Fisher (1878-1949) from the American Museum of Natural History, and the director of the astronomical Hayden Planetarium. Fisher was a well-known editor (e.g., The One Volume Nature Encyclopedia, the popular-science Sky-Magazine of Cosmic News), and wrote several multiply issued books on astronomy. Primary interests of Fisher included also meteoritic craters (Fisher, 1934). He wrote in 1936 a well-illustrated article on Estonian craters for Natural History, the journal of the American Museum of Natural History. Fisher described thoroughly "evidence of an astronomical collision that occurred perhaps two thousand years ago" after his visit in Estonia in the summer of 1936. He contacted Ernst Julius Öpik, well-known astronomer from the Tartu Observatory (see below), and was guided to the craters by Reinwald (Fig. 8A), introduced as the one "who... had been the first to conceive and announce to the scientific world the correct theory of their origin". In the context of missing decisive proof, namely meteoritic fragments, Fisher mentioned: "How quickly the meteoric iron has disappeared from Meteor Crater in Arizona and from the Henbury Craters in Australia with the influx of people!... The Kaali Craters in Estonia are located in arable land that has been tilled for hundreds of years, thus providing ample time for the iron to be carried away. And then some forms of meteoric iron oxidize and disintegrate very rapidly... Reinvald maintains that it is absolutely futile to search for the 'main mass' of the meteorite in the crater itself, even if pieces should be found lying around" (Fisher, 1936, pp. 295-296).

Nevertheless, the query for meteoric iron was soon successful by Reinwald in course of continued field works (Fig. 7C; Fisher, 1938). After this discovery, Fisher presented the Estonian craters in 1937 at Fifth-Ninth Meeting of American Astronomical Society, Bloomington, Indiana (Fisher, 1939). At brief, the Fisher's emphatic proclamation was clearly 
reasoned: "The most interesting spot on Earth is the designation said to have been given by the great Swedish scientist Arrhenius to Meteor Crater in Arizona. Little did he suspect the existence of a whole group of such craters at his own back-door-step, as it is there" (Fisher, 1936, p. 292).

\subsection{Estonian crater issues in the Soviet epoch}

The Kaali crater field persisted three decades in the mainstream science as a sole European "footprint left by visitors from outer space" (in words of Fisher). This designation was highlighted also by the well-known Soviet expert in meteoritics, Yevgeny L. Krinov (1906-1984) in 1960 (also anonymous, 1960), although earlier Soviet literature questioned the meteoritic nature of Kaali craters ("pseudo-meteor craters" of Chirvinskiy, 1931). Krinov indicated also for the Kaali meteorite shower that, whilst the major crater represents a true explosion crater, the smaller ones are non-explosive impact structures (= penetrative craters sensu Racki et al., 2018), that contain preserved exclusively iron material (Krinov, 1961).

Ivan Reinwald also proposed the admirable idea of a natural reserve, with some craters protected in pavilions, coupled with Open air Meteor Crater Museum, as the geotouristic attraction of the area (Reinwald, 1940; also Krinov, 1960), a proposal reconsidered nowadays (Raukas and Stankowski, 2010). After occupation of Estonia by the Soviet army in 1940, another Soviet authority (thanks to the study of Tunguska impact), Leonid A. Kulik (1883-1942; born in Tartu), promoted the realization of this huge project, paired with research works on Kaali craters (see Aaloe, 1963 and Plado, 2012, for review of the real progress). He placed the project in a distinctive geopolitical viewpoint: "What was not in the power of a tiny capitalist Estonian state is by any means feasible in the huge Soviet Union" (Kulik, 1940, p. 65).

In Estonia independent again, the subsequent studies on the Kaali crater field focused on its refined dating, sub-surface crater morphology and associated meteoritic matter (e.g., Raukas et al., 2005; Raukas and Stankowski, 2010, 2011; Plado, 2012; Zanetti et al., 2015), but also on ecological and social effects of the impact (Veski et al., 2007). In particular, the age of impact was precised as recent as $3237 \pm 10$ years ago, in light of ${ }^{14} \mathrm{C}$ dating charcoal within proximal ejecta (Losiak et al., 2016).

\section{Though-provocative Kaljuvee's 1933 book}

In his 1933 dissertation, Kaljuvee began with the description of the craters and continued the search in literature and on the Earth maps for the crater forming elements and analogues. His objective was to integrate these elements together with physical and chemical scientific facts and their interpretation into models, toward an overall theory of Earth evolution. In consequence, the discourse includes surprisingly innovative conceptions that could be regarded as a manifest of forthcoming neocatastrophism culmination since 1980s, partly rooted in the classical French catastrophism (see below). On the other hand, several of his general "intuitive" ideas are totally unacceptable from the viewpoint of recent science, being an effect of an uncritical Kaljuvee's imagination without physical basis, that have led him finally even to obsolete, pre-Enlightenment cataclysmic conceptions.

Kaljuvee used distinguished textbooks, such as Kayser's Lehrbuch der Geologie (1918-1924) and Bubnoff's (1931) Grundprobleme der Geologie, as examples and sources for his synoptic studies. However, he had a special interest and respect for Alfred Wegener's theory of dynamic Earth (e.g., 1912; Köppen and Wegener, 1924). Inspired by Wegener, Kaljuvee discussed at length late Cenozoic continental glaciation, but also the continental drift, tectono-volcanic processes and climate change issues.

\subsection{Impact origin of large Bavarian Ries crater}

The transfer of the meteorite impact notions from the United States to Germany was very limited till 1930s, despite several mostly popular-science papers, and a few excursions to Arizona on occasion of international meetings (Fig. 1). Conversely, "an enormous caldera at Ries" had been promoted as a model for the Coon Butte during the 1912 Transcontinental Excursion (anonymous, 1912b). Thus, this remarkable circular depression in Bavaria, $25 \mathrm{~km}$ in diameter and $200 \mathrm{~m}$ deep, was since 1792 continuously viewed as somewhat putative but the leading example of hydrothermal explosion (as "an embryonal volcano"; phreatomagmatism in recent terms); the cryptovolcanic idea was propagated for impact craters till 1960s (Bucher, 1963). This intricate history of the Ries crater studies is fully described in the recent monograph of Kölbl-Ebert (2015), who exposes the pioneering role of the "impactist renegade", Julius Kaljuvee.

Even if there were two earlier German proponents of the impact origin for the mysterious cirque in Swabian Alb, namely Werner (1904) and Meydenbauer (1906), only the more extended mention is included in the latter paper. In fact, the Meydenbauer note was the first European systematic search for real geological evidence of cosmic scars (omitted by Kölbl-Ebert, 2015; see Tab. 1). Albrecht Meydenbauer (18341921), architect and co-founder of photogrammetry, was an active advocate of the meteoritic lunar hypothesis at the turn of the 19th and 20th centuries. He regarded Ries structure as the most likely impact candidate in Germany (guided by highly disturbed geological succession in the locality). On the other hand, fortunately, another "renegade", Rohleder (1933) gave a "last-minute" credit for Kaljuvee in the context of convincing meteoritic model for the Ries crater.

Kaljuvee (1933, pp. 113-120) presented exhaustive discussion on "a geological puzzle" of Nördlinger Ries, as well as the associated 3.8-km-wide Steinheimer basin. He finally concluded that " a cosmic body, worth of making the Ries basin, must have been able to penetrate the Earth's crust; the lava flowing back into the resulting orifice could also reach up to the surface of the depression, then only the assumption of a meteorite disaster, and indeed a double blow, can completely explain the riddles of the Nordlinger Ries and Steinheimer Becken. In our case, this assumption offers even more: it explains an appearance in their immediate neighborhood, again in a much more rational way than has hitherto been done. This refers to the 127 through-cavities together with funnel craters at Urach" (Kaljuvee, 1933, p. 118; see KölblEbert, 2015, p. 31). 
Suggestions on lava outpouring triggered by meteorite fall in the impact-shocked area were presented earlier (e.g., Schwarz, 1909; Beaumont, 1925). Unique aspect of the Kaljuvee's hypothesis includes the causal linking of catastrophic impact with magmatic activation and eruptive volcanism onset far outside the crater, in the distant region of the Swabian Alb (Bad Urach today), ca. $40 \mathrm{~km}$ west of the Steinheim Basin. Nowadays, it is evident that the diatremes hold records of volcanism at least 3 million years younger than the impact. In brief, however, this propagation of impact energy remains an attractive notion, even if being a polemical matter still in the 21 st century (e.g., Ivanov and Melosh, 2003). New evidence in Richards et al. (2015) rejuvenates the idea that, in result of Chicxulub impact, seismic waves initiated the enormous lava flows in the Deccan Traps province (i.e., on the opposite side of the globe) that led to the dramatic ecosystem collapse at the end of the Cretaceous period.

In addition, Kaljuvee performed an experiment with compressed paraffin and stearin layers to produce laccolitelike structure, seen as "as a consequence of the giant meteorite catastrophe". Hence, summarizing the Ries-Steinheimer case study in a broad research perspective, he noted: "in a meteorite impact corresponding to the giant crater, we have a case which has also been of a catastrophic importance for the crust of the Earth, and contains elements of small dimensions, which are characteristic in all great mountain formation processes, namely thrusts with crush breccias [Reibungsbrezzien] and massive volcanic eruptions" (Kaljuvee, 1933, p. 120).

\subsection{Cosmic catastrophes and mass extinctions}

It was as early as in 1916 that young Russian geologist Mikhail A. Usov considered the case of Meteor Crater as a starting point to a discussion of probable causal link between extraterrestrial factors and global catastrophes in the Earth history (Usov, 1916). This notion was extended by Kaljuvee (1933), with the following fascinating mention concerning "a hitherto undervalued geological factor" - large-body impacts: "Since the meteorites should finally be included in the category of heavenly bodies the dimensions of which may vary from asteroids of some dozens of kilometers in diameter up to giant stars and central bodies million times bigger than our Sun. But the fall of meteorites should necessarily be caused by a collision of heavenly bodies which for the meteorites should be catastrophic. Nevertheless the astronomy has ascertained the igniting of stars often up to the first magnitude, the so-called Nuovas [Novas], at a distance of several tens of thousands of light-years which necessarily means that the collisions of giant masses must have happened there. So it should have happened also on the Earth where collisions with heavenly bodies, bigger than the assumed meteorite in the Canyon Diablo must have happened. But there are no traces of collisions, say with the asteroids of average size. It is self-evident, however, that such collisions with larger heavenly bodies are less likely to occur, the larger the body is, but the geological ages are already so long that collisions of the earth with bodies of medium asteroid size may be a fact" (Kaljuvee 1933, pp. 112-113).

Kaljuvee speculated further in his book on possible farreaching and diverse terrestrial records of the cosmic collisions. Obviously, for Kaljuvee also the biosphere history was determined of recurring "Earth revolutions". With reference to the Cuvier's catastrophism, discussed by Bubnoff (1931) in biozonation context, and post-Darwinian saltational/ mutation evolution models, he briefly considered causal links between "paleontological, orogenetic, and epirogenetic" records.

Kaljuvee (1933, p. 13) maintained that “...if the Cuvier's method (Orientierungsmethode) should afford advantages here, then [1] we need a partial extinction instead of 'complete extinction', and instead of 'new creation', [2] we must recourse to saltational evolution (de Vries) [1901-1903] as a result of changed life conditions, at times even a slow development, especially in those already less responsive to minor changes in the life conditions, the invertebrates [an example of Jurassic ammonites after Brinkmann, 1929]... Of course, great development periods cannot be taken more actualistically, as major catastrophes due to the impact of larger cosmic bodies on the Earth often occur only after pauses of millions of years".

It should be stressed that, perhaps after Bubnoff (1931), only general acceptance of the Cuvier doctrine by Kaljuvee was influenced by an alleged theology-related anti-evolutionary aspect of the early 19th century theory ("Perhaps it could be the suggestion that in our remarks we actually revive the already outdated and finally condemned cataclysmic hypothesis of Cuvier. It is not quite so... While Cuvier's catastrophes destroyed all the Earth's fauna and flora and postulated a general re-creation, so radical output is the broken out in reality not to write to"; Kaljuvee, 1933, p. 78). Thus, Kaljuvee's idea of "a partial destruction" in contrast to "total destruction" was indeed replication of the truly original extinction-migration Cuvier's scenario, as at length discussed already by Depéret (1907). However, the "unscientific" creationistic label is repetitively attributed to Cuvier even in recent textbooks and encyclopedias in the Anglophone world (e.g. Wicander and Monroe, 2009, p. 70; Rauch, 2011; see also Ward and Carozzi, 1984, p. 18).

Although the impact-triggered mass extinction scenario was not directly addressed, the Cuvierian catastrophic aspect was evidently present in the remarks, integrated with scenario of tectonism-controlled cyclic cataclysmic changes in the evolution of terrestrial life (see similar but non-impact European theories at that time in Seidlitz, 1920 and Sobolev, 1928; Jagt-Yazykova and Racki, 2017). Hence, Kaljuvee (1933, p. 131) stressed that "the accumulation of the mountains by the impulse of a giant meteorite must also take place, but here it happens catastrophically fast". "The impulse of a giant meteorite", he thought, was an all-embracing prime cause of the global turnovers, including the then unknown causes of continent wandering and glaciations.

\subsection{Wegener's dynamic Earth and impact control on Pleistocene glaciations}

When reading the Kaljuvee 1933 work, one gets a feeling that the impact model emerged from comparing the descriptions of an important quartet: the American Arizona Meteor (diameter $1.18 \mathrm{~km})$, Kaalijärv $(0.11 \mathrm{~km})$, Steinheim $(3.8 \mathrm{~km})$, and Nördlingen-Ries $(24 \mathrm{~km})$, of which only meteoritic origin of the Arizona's crater was proven at the time. However, Kaljuvee was so confident in his interpreta- 


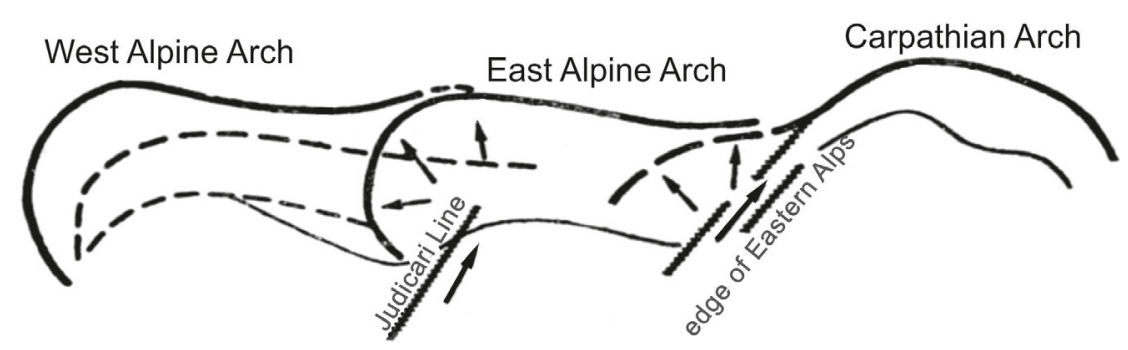

Fig. 9. Scheme of tile-shaped overlapping of Alpine arcs (arrows show a movement direction; after Bubnoff, 1931), as a starting point to their interpretation by Kaljuvee (1933, fig. 34 therein) as successive crust displacements due to three following giant tangential impacts in the Mediterranean Sea basin.

tions and virtual models that he began to interpret the structures that were much larger than these four. Based on our present knowledge, we see the basic weaknesses in Kaljuvee's discussions in describing numerous real and hypothetical examples. In particular, he assumed that the shape of the meteorite explosion structures on the ground depends on the incident angle of the falling body: the vertically falling body forms a symmetrical round shape, and an elongated structure results from an inclined trajectory. It is noteworthy that the Estonian astronomer Ernst Julius Öpik (1893-1985), recalled above, had already solved this problem in 1916, showing that the conversion of energy during an impact caused an explosion creating a circular crater irrespective of the angle of impact (Öpik, 1916; see the historical review in Racki et al., 2014).

Unfortunately, Kaljuvee did not know Öpik's work, which was published in an obscure journal and therefore his revolutionary hypothesis could not rightly explain a large tangential force to the crust when the falling meteorites are incident at low angles. The conjunction of mountain ranges composed of tectonic sheets, with indications of tangential pressure and deformation of the crust was among the most important observations of Kaljuvee. The fixist geosynclinals theory has not been able to explain these phenomena. Kaljuvee also assumed that the vast meteoritic explosions produced massive faults in the Earth, like those where the Mediterranean and the Red sea are situated (Kaljuvee, 1933; pp. 132-133). However, with the jump from small impact structures to large (hundreds and thousands of kilometers) bow-shaped mountain ranges (e.g., Alps - Fig. 9), he exceeded the limits of the use of analogies.

As stressed above, the Wegener's continental drift hypothesis particularly attracted Kaljuvee. In fact, Holmes (1931) considered the radioactive decay as the heat source to convection currents in the mantle, and also as the driving force to the drift. This idea was essentially undervalued till the paper of Wilson (1963), and so Kaljuvee was inspired by the special significance of the recurrent meteorite impacts in the history of the development of the Earth's crust. This led him to the integration of Wegener's dynamic Earth model and the potential consequences of his own hypothesis of meteoritic bombardment, to the extent that, as expressed by Kölbl-Ebert (2015, pp. 132-133), "for Kaljuvee, impacts explained everything from orogenesis and plutogenesis to large volcanic eruptions", and moreover "that the enormous bombardment of the Earth was responsible for a large increase in its mass, which was responsible for the fact that the continents would no longer fit together in a closed shell (Kaljuvee, 1933: 123162)". In original presentation by Kaljuvee (1933: 162): “The Earth has not only grown yearly by 20000 tons as indicated by Arrhenius [1913: 113-114] but the increase of the mass through large cosmic projectiles shadows the increase in the sense of Arrhenius. These cosmic bodies, which have penetrated into the magma of the Earth, have perhaps also brought as a result of braking with them the heat of melting necessary for their liquefaction, but chiefly the main part for the increase of the Earth magma mass. The original sial coat of the Earth had become too small! Gea is outgrown from her youth dress!"'. However, the exciting idea of expanding Earth mass (and size?) in the wandering continents context was in fact limited to this only ending mention in the discourse.

On the other hand, a tangential blow of a large meteorite that could lead to a displacement of the planetary axis and the migration of poles was another stunning notion of Kaljuvee. He thought that this shift of poles led to a simultaneous late Cenozoic glaciation of North America and North Europe. In spite of a slow rate of major geological processes advocated by Wegener (and also by Bubnoff, among others), Kaljuvee repeatedly stressed their rapidly cataclysmic characters. His "new catastrophic theory" was summarized as follows: "The causes of larger Earth revolutions (diastrophes) are impacts of large cosmic bodies with the Earth. Only in such a way one can explain simultaneous engagement of orogenesis and plutogenesis, belonging causally together, and the contradiction between the agglomeration of the crust (earlier named as contraction) and volcanic mass eruptions (earlier as a consequence of pressure of the Earth's crust)" (Kaljuvee, 1933, p. 125).

Noteworthy, the Chicxulub impact event at the CretaceousPaleogene boundary has indeed been enormously catastrophic in planetary scale (Alvarez et al., 1980; Hoyt, 1987; Palmer, 2003; Racki, 2012b; Powell, 2015), albeit in a somewhat different way than Kaljuvee could have foreseen; by the way, his impact-driven floods and transgressions have been recently interpreted as tsunamis. Kaljuvee heuristically looked for the sedimentary record of the impact episodes ("Riesenbreccia", "huge gravelmasses", "bone-rich deposits", tektites). For the putative largebody Pannonian impact near the Eocene-Oligocene boundary Kaljuvee predicted that: "In the case of the projectile falling in the Hungarian lowland, the friction had to grow very high and gasifying the projectile into most glowing cloud which could turn the terrestrial cloud-making into a joke. It is more than probable that these clouds had to condense into heavy liquid rock drops 
and to fall in a wide range. We now have them again in the much controversial mold shapes, which are not bigger than nuts, made of moldavites-obsidian-like molten stones of meteoritic composition in countless quantities" (Kaljuvee, 1933, pp. 123-124). Importantly, the impact-produced melt origin of moldavite has not been approved before 1960s (Gentner et al., 1963), even if a cosmic origin of the green glass was indicated already by Suess (1901).

\subsection{Response to the Kaljuvee 1933 discourse}

As noted by Kölbl-Ebert (2015, p. 32): "It seems that Kaljuvee was read by his contemporaries, but it is not surprising that his largely esoteric ideas were mainly disregarded". In fact, this challengingly neocatastrophic book was referenced/abstracted or even reviewed in numerous German geo-journals, such as Zeitschrift der Deutschen Geologischen Gesellschaft, Geographische Zeitschrift (Rüger, 1933), Neues Jahrbuch für Mineralogie, Geologie und Paläontologie, Petermanns Geographische Mitteilungen, Gerlands Beiträge zur Geophysik, Geologie und Bauwesen, and Geologisches Zentralblatt, but even also in Hungarian (Földtani Közlöny), Swedish (Sveriges Offentliga Bibliotek) and Finnish (Terra. Suomen Maantieteellisen Seuran Aikakauskirja) periodicals. Furthermore, a similar response can be found in English-language periodicals, such as Mineralogical Abstracts, Contributions of the Society for Research on Meteorite (La Paz, 1941), and Popular Astronomy.

In particular, in an anonymous review for the Geographical Journal anonymous, 1934 (P.L., 1934), the author diagnosed the general Kaljuvee's vision of the Earth history as follows: "he belongs to the catastrophic school of geology, which became almost extinct last century, but has revived since the war. His catastrophes are due to the impact of cosmic bodies of a size undreamed of by Dr. Spencer [1933]; otherwise he is a disciple of Wegener, to whom he dedicates his book. The gigantic meteorites imagined by the author break up the sial sheet and separate the fragments, cause transgressions of the sea and movements of the pole, and raise mountain chains. They solve, in fact, the chief difficulties that Wegener leaves unexplained".

In subsequent decades of the 20th century, the significance of the 1933 book was limited to the conclusive confirmation of meteoritic origin of the Bavarian structures (e.g., Hörz, 1965; Engelhardt, 1982; Hölder, 1989; Stöffler et al., 2013), and the Kaljuvee's priority was fully honoured by Kölbl-Ebert (2015). Conversely, his extreme extraterrestrially-driven catastrophism was almost unnoticed in the next wave of neocatastrophic papers, especially flourishing after the conclusive contribution by Alvarez et al. (1980). His compatriot Ernst Julius Öpik (1958) could be a leading example of such an attitude (see Racki, 2012a; Racki et al., 2014). In truth, the extravagance of the premature Kaljuvee theory, especially concerning wandering continents, is a distinguishing feature even when compared to several other all-embracing eccentric works in the pre-Alvarez epoch, being harbingers of neocatastrophism in Europe (Beaumont, 1925; Morozov, 1930) and the United States (Nininger, 1942; Kelly and Dachille, 1953). The only matching, also truly impact/ cataclysmic theory, was totally independently proposed 30 years later by Gallant (1964, Fig. 10 herein; see also $e$. g., "impact geology" of Kelly, 1985). So far-reaching hypotheses in "impactology" have been generated outside professional scientific centers, where the mainstream Lyellian paradigm was an obvious limitation for any speculative scenarios (see Torrens, 1998).

\subsection{French roots of Kaljuvee's neo-catastrophism, and other conceptual affinities}

The above quoted assignment of Julius Kaljuvee to the slowly reviving catastrophic school is indeed paired with several conceptual links between him and the French fathers of this theory. Particularly, the above quoted Kaljuvee's claim on inevitable probability of large-body impacts ("the geological ages are already so long that collisions of the Earth with bodies of medium asteroid size may be a fact"; Kaljuvee, 1933, p. $113)$ is in a clear correspondence with unrecognized conclusion of Laplace (Racki, 2015). This leader of French Revolution science analyzed the likelihood of a comet collision with Earth in his landmark astronomical treatise of 1796. On a historical timescale ("in the course of a century"), Laplace supposed, the probability of such a cosmic disaster was minimal (Laplace, 1796, p. 61), but he finally concluded, "Nevertheless, the small probability of this circumstance may, by accumulating during a long succession of ages, become very great". So, extraterrestrially-driven catastrophes were inescapable in the geological time (formulated as theory of rare events 170 years later by Gretener, 1967; see Shoemaker, 1962 , Hsü, 1989; Racki, 2015), and eventually proven by Alvarez et al. (1980). In this context, Kaljuvee's brief considerations on evolutionary consequences of the impact catastrophes were placed in the broad conceptual setting of Cuvier's (1812) extinction doctrine. The periodicity of the impact-stimulated ecosystem perturbations, on a $20-30 \mathrm{Ma}$ time scale, is a principal theme recently (e.g., Rampino, 2017), and the vigorous discussion shifted rather toward global effects of "serial killer mantle plumes" (e.g., Courtillot and Olson, 2007). On the other hand, the abruptness of cyclic mountain-building processes, promoted by Kaljuvee (1933), recalled an original cataclysmic theory of orogenic revolutions proposed by Élie de Beaumont (1829-1830).

Surprisingly, the Kaljuvee's scenario of meteorite-modified Earth axis and following glaciation corresponds to some rationales initiated in the cometary theologically-rooted catastrophism of the late 17th century (since Hooke and Halley to Laplace; see review in Schechner Genuth, 1997). Similar ideas were revived still in the late 20th century (Gallant, 1964; Kelly, 1985). On the other hand, Kaljuvee has followed a search for analogy of bowl-like terrestrial mountain ranges with crater-like structures following the approach of Kant (1785), Élie de Beaumont (1831, 1843), Rozet (1846), among others, and summarized by Hauslab (1862). These authors in particular stressed the similarity of Bohemia and Ceylon "annular" geomorphology to lunar ring-mountain arcs, considered them as enormously large volcanic craters. However, in the later interpretations, many giant-scale ring-like terrestrial structures were thought by Gruithuisen $(1844,1845)$ and Meydenbauer (1890) as huge meteoritic scars (Tab. 1). In addition, even meteoritic origin of the Pacific basin was hotly discussed in the 1960s by several authors (e.g., Gilvarry, 1961; Gallant and Dietz, 1963; see review by Bourgeois and Koppes, 1998). 

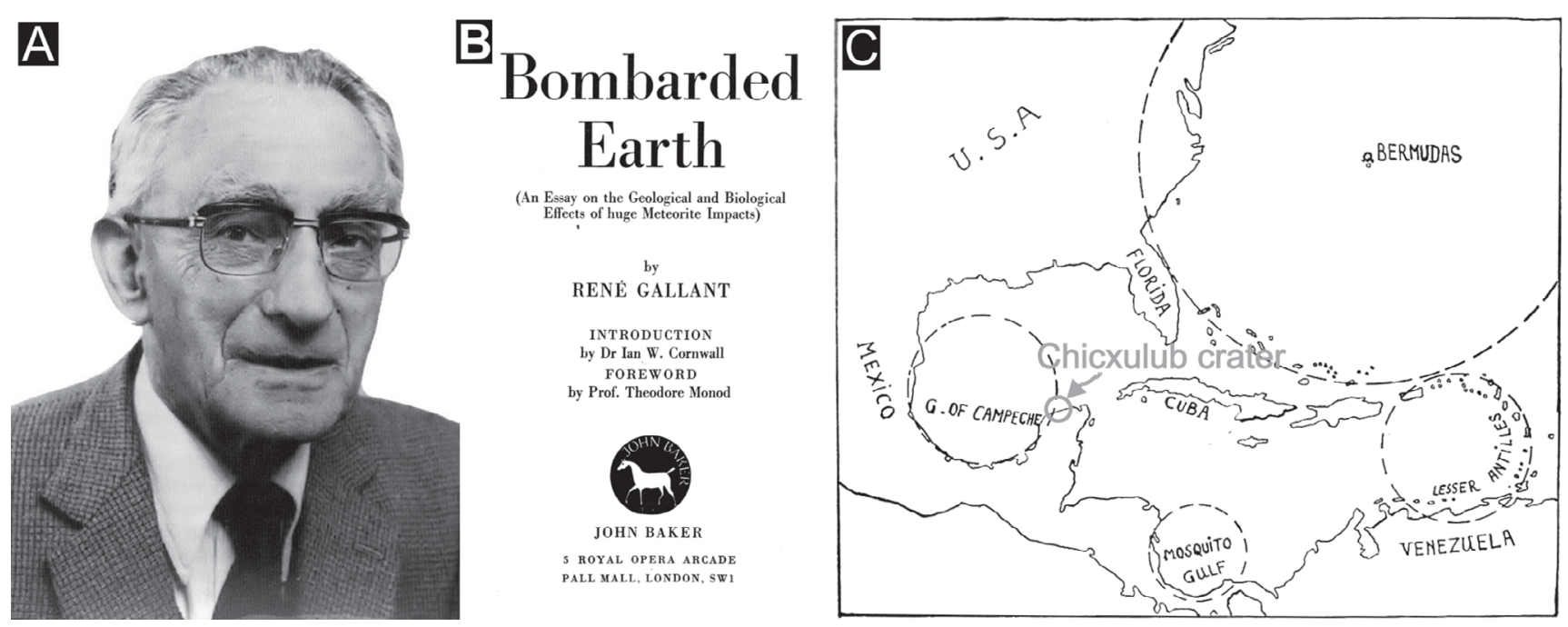

Fig. 10. René L.C. Gallant (1906-1985), Belgian colonel, mathematician-engineer and amateur geologist (A), author of the truly neocatastrophic interdisciplinary essay Bombarded Earth (1964; title page, B), presenting an independent hypothesis of cosmic catastrophism, but in fact very similar to the 1933 concept of Kaljuvee (i.e., giant meteorite impacts as the cause of shifts of the Earth axis, resulting in orbital changes, the slip of crust and continent drift, mountain-building, volcanism, and climate change; see Torrens, 1998). Gallant supposed occurrence of many huge "cosmic scars", exemplified herein by the Caribbean region (indicated by circles; C), as well as location of the real Chicxulub crater (grey circle) for comparison.

Correspondingly, the scenario of intense "meteoritic bombardment", so highlighted by Kaljuvee, is recently limited to a cataclysmic asteroid-meteorite impact interval in the early Precambrian Earth history and "proto-continental growth" (Grieve, 1980; Kuzmin et al., 2016), and synonymized with the Late Heavy Bombardment that affected the inner Solar System between 4.0 and 3.8 billion years ago (Claeys and Morbidelli, 2011). The seemingly "wild" notions of Kaljuvee, placed in the holistic cognitive framework of the evolving Earth system, are only a variety of recurring attractive challenges in geohistorical considerations.

Kaljuvee was well aware of incipient knowledge in many overall impact-related aspects discussed by him, and in reference to Alfred Wegener, he recapitulated: "in a personal letter dated October 4, 1927 to the author, ... A. Wegener admitted that the biological facts today no longer necessitate an unconditional rejection of the theory of catastrophes. By the way, Wegener was still skeptical about such an assumption. But we want to continue to work in this direction and hope in this way to deliver the missing A. Wegener's theories" (Kaljuvee, 1933, p. 78). This belief was fully realized only in the last revolutionary decades of the 20th century (e.g., Marvin, 1986; Hoyt, 1987; Kolchinsky 2002; Powell, 2015; Rampino, 2017), as summarized by French (1998, p. 1): "During the last 30 years, there has been an immense and unexpected revolution in our picture of Earth and its place in the solar system. What was once a minor astronomical process has become an important part of the geological mainstream... Impact events have generated large crustal disturbances, produced huge volumes of igneous rocks, formed major ore deposits, and participated in at least one major biological extinction".

\section{Summary and implications}

Since their discovery in 1827, the views on Estonian craters have undergone a historical evolution comparable particularly with the Meteor Crater: from volcanic (maar-type) and sinkhole models to meteoritic hypothesis in the early 20th century. On the other hand, however, the historical proposals, mostly of the Baltic German provenance, were uniquely diverse, because include so peculiar proposals as man-made surface transformations, natural gas self-explosion and clay bulge (Spencer, 1938 listed a total 8 hypotheses).

Julius Kaljuvee, an amateur "theoretical" geologist, was an initiator of original thinking about Kaali craters in terms of meteorite impact already in 1922, developed by him in the discourse of 1933. In the meantime, the applied geologist Ivan Reinwald performed exhaustive field studies of the crater group. His discovery of the original meteoritic material in 1937 was the final proof for the first recognized European impact structure, and the only one till 1960s. So, these two persons were in a favorably complementary relation in their scientific activity.

In addition, American and British publications, as well as a uniquely international cooperation realized by Reinwald have contributed to the immediate worldwide acceptation of the Estonian structures in mainstream English-language science, as undoubted impact localities already in the 1930s. Unsurprisingly, therefore, the Estonian craters were present in the succeeding accounts on more and more numerous "authenticated" meteorite sites of Spencer (1933), Heide (1934), Watson (1936), Boon and Albritton (1938), Hey (1940), Leonard (1946), Freeberg (1966) and Grolier (1985).

Kaljuvee presented some pioneer concepts in his basic work of 1933. He first proposed an impact origin of large Ries "caldera" (confirmed 30 years later due to finding of highpressure/temperature minerals; see Kölbl-Ebert, 2015), as well as looked for a diagnostic sedimentary record of the collisions, like in brecciated deposits, tektites and anomalous flood deposits. Furthermore, he was also the first to causally link the meteorite strikes with volcanic activation in distant areas, due to hydrostatic relaxation of impact energy. Nevertheless, 
several other Kaljuvee's hypotheses of extremely large-body impact-generated phenomena, including continental drift, are unacceptable today due to unrealistic conceptions of physical processes involved in cratering. Thus, the 1933 book is certainly a record of unique erudite activity, but not an unrecognized landmark neocatastrophic theory.

For Kaljuvee, inspired by Alfred Wegener, the geological history should be seen holistically in the context of integrated geological, climatic and biological phenomena, but primarily controlled by falling large cosmic bodies in intervals of millions of years (= of periodic geological revolutions). In the Kaljuvee's considerations it is evident that the direct or indirect links to various catastrophic notions, refuted at that time but regained in the mainstream model science after success of the meteoritic hypothesis by Alvarez et al. (1980; see discussion and other examples in Maher, 1998; Racki et al., 2014; Racki, 2015; Jagt-Yazykova and Racki, 2017). Despite their peripheral starting point, several revived Kaljuvee's ideas re-appeared therefore expectedly in the neocatastrophic paradigm in geology for the 21 st century (see Rampino, 2017).

\section{Supplementary Material}

Supplementary File contains key fragments of the Kaljuvee 1933 dissertation on Kaali and Ries craters and concluding remarks, translated from German by Tõnu Viik.

The Supplementary Material is available at https://www.bsgf. fr/10.1051/bsgf/2018011/olm.

Acknowledgements. The author sincerely thanks an anonymous journal reviewer for his thoughtful and constructive review. We thank also Tomasz Wrzołek for thorough final examination of the draft, as well as Maria Lushchik, Liisi Esse and Marco Romano for providing some literature items.

\section{References}

Aaloe A. 1961. I. Reinwald. Eesti Loodus 1961(4): 234-235. In Estonian.

Aaloe AA 1963. On the history of the study of the Kaali meteorite craters. Inst Geol Akad Nauk Estonskoy SSR, Trudy 11: 25-34. In Russian.

Alvarez LW, Alvarez W, Asaro F, Michel HV. 1980. Extraterrestrial cause for the Cretaceous-Tertiary extinction. Science 208: 10951108. DOI: $10.1126 /$ science.208.4448.1095.

Andrée K. 1932. Die Geophysikalische Warte der AlbertusUniversität, ihre Aufgaben und ihre bisherigen Arbeiten. Ostdeutscher Naturwart 4(5): 182-187.

anonymous [Klein HJ.?] 1908. Vorgeschichtlicher Aufsturz eines grossen kosmischen Körpers auf die Erde. Sirius 41: 199-201.

anonymous 1912a. Le cratère de Canon Diablo. Le Cosmos 66: 478. anonymous $1912 \mathrm{~b}$. Savants make researches in high Rockies. Divided in theory about Meteor Crater. Salt Lake Tribune 85 (182, October 13, 1912): 10 [In a less complete version as "Scientists' study of Meteor Crater. Geographers divided between theories of aerolitic and volcanic origin", New York Times 62(19,979, October 6, 1912): $\mathrm{X}(81)]$.

anonymous (P.L.) 1934. Review: Die Grossprobleme der Geologie by J. Kaljuvee. Geogr J 82: 84-85.

anonymous 1960. Les seuls cratères de météorite connus en Europe. La Nature 88: 503.
Arrhenius S. 1913. Das Werden der Welten. Leipzig: Akademische Verlagsanstalt.

Barringer DM. 1905. Coon Mountain and its crater. Proc Acad Nat Sci Philadelphia 57: 861-886.

Barringer DM. 1909. Meteor Crater (formerly called Coon Mountain or Coon Butte), in northern central Arizona [read before National Academy of Science, Princeton University at its Autumn Meeting at Princeton University, November 16th 1909]. Privately printed.

Beaumont C. (written under the name of Appian Way) 1925. The Riddle of the Earth. London: Chapman \& Hall.

Bergeron J. 1913. Sur les relations qui semblent exister entre les accidents anciens de la surface de la terre et ceux qui ont pu se produire durant le stade lunaire de notre planète. Bull Soc géol Fr 4 (13): 323-341.

Boon JD, Albritton CC. 1938. Established and supposed examples of meteoritic craters and structures. Field and Laboratory 6(2): 44 56.

Bourgeois J, Koppes S. 1998. Robert S. Dietz and the recognition of impact structures on Earth. Earth Sci Hist 17: 139-156. DOI: 10.17704/eshi.17.2.t05vj1571716t462.

Brinkmann R. 1929. Statistisch-biostratigraphische Untersuchungen an mitteljurassischen Ammoniten über Artbegriff und Stammesentwicklung. Abh Ges Wiss Göttingen, Math-Phys Kl N F 13: 1249.

Bubnoff S. von 1931. Grundprobleme der Geologie: Eine Einführung in geologisches Denken. Berlin: Gebrüder Borntraeger.

Bucher WH. 1963. Cryptoexplosion structures caused from without or from within the earth? ("Astroblemes" or "geoblemes"?). Am J Sci 261: 597-649. DOI: 10.2475/ajs.261.7.597.

Calciati C. 1913. L'escursione geografica transcontinentale 1912 negli Stati Uniti d'America. Boll Soc Geogr Italiana 50: 471-513.

Chirvinskiy PN. 1931. On pseudo-meteor craters in Arizona and Oesel island. Zap Ross Mineral Obsh 60: 135-144. In Russian.

Claeys P, Morbidelli A. 2011. Late Heavy Bombardment. In: Gargaud M, et al., eds. Encyclopedia of Astrobiology. Berlin: Springer, pp. 909-912. DOI: 10.1007/978-3-662-44185-5_869.

Courtillot V, Olson P. 2007. Mantle plumes link magnetic superchrons to Phanerozoic mass depletion events. Earth Planet Sci Lett 260: 495-504. DOI: 10.1016/j.eps1.2007.06.003.

Cuvier G. 1812. Discours Préliminaire. In: Recherches sur les Ossemens Fossiles de Quadrupèdes. Paris : Deterville, pp. 1-116.

Depéret C. 1907. Les transformations du monde animal. Paris: E. Flammarion.

Drake ET. 1985. The Coon Butte Crater controversy. Geol Soc Am Centennial Spec 1: 65-78. DOI: 10.1130/DNAG-CENT-v1.65.

Eichwald E. 1854. Dio Grauwackenschichten von Liev- und Estland. Bull Soc Imper Nat Moscou 27: 4-111.

Élie de Beaumont L. 1829-1830. Recherches sur quelques-unes des révolutions de la surface du globe. Ann Sci Nat 18: 5-25, 284-417, 19: 5-99, 177-240.

Élie de Beaumont L. 1831. Sur les rapports qui existent entre le relief du sol de l'île de Ceylan et celui de certaines masses de montagnes qu'on aperçoit sur la surface de la Lune. Ann Sci Nat 22: 88-96.

Élie de Beaumont L. 1843. Comparaison entre les masses montagneuses annulaires de la Terre et de la Lune. $C R$ Acad Sci Paris 16: 1032-1035.

Engelhardt W. von 1982. Hypotheses on the origin of the Ries Basin, Germany, from 1792 to 1960. Geol Rundsch 71: 475-485. DOI: 10.1007/BF01822378.

Fairchild HL. 1907. Origin of Meteor Crater (Coon Butte), Arizona. Bull Geol Soc Am 18: 493-504. DOI: 10.1130/GSAB-18-493.

Fisher C. 1934. Where a comet struck the Earth. Nat Hist 34: 754762. 
Fisher C. 1936. The meteor craters in Estonia. Nat Hist 38: 292-299. Fisher C. 1938. Exploring Estonian meteor craters. Sky-Magazine of Cosmic News 2(5): 8-9.

Fisher C. 1939. The Estonian meteor craters. Publ Am Astron Soc 9: 120.

Foote AE. 1891. A new locality for meteoric iron, with a preliminary notice of the discovery of diamonds in the iron. Am J Sci 42: 413417. DOI: 10.2475 ajs.s3-42.251.413. [Reissued in Nature 45 (1891): 178-180. DOI: 10.1038/045178a0].

Freeberg JH. 1966. Terrestrial impact structures - a bibliography. US Geol Surv Bull 220: 1-91.

French BM. 1998. Traces of catastrophe: A handbook of shockmetamorphic effects in terrestrial meteorite impact structures. Houston, Texas: Lunar and Planetary Institute.

Gallant R. 1964. Bombarded Earth: An Essay on the Geological and Biological effects of Huge Meteorite Impacts. London: J. Baker.

Gallant RLC, Dietz RS. 1963. Meteorite impacts, lunar maria, lopoliths and ocean basins. Nature 197: 38-40. DOI: 10.1038/ 197038a0;10.1038/197039a0.

Gentner W, Lippolt HJ, Schaeffer OA. 1963. Argonbestimmungen an Kaliummineralien- XI. Die Kalium-Argon-Alter der Gläser des Nördlinger Rieses und der böhmisch-mährischen Tektite. Geochim Cosmochim Acta 27: 191-200. DOI: 10.1016/0016-7037(63) 90058-9.

Gilbert GK. 1896. The origin of hypotheses illustrated by the discussion of a topographic problem. Science 3: 1-13. DOI: 10.1126/science.3.53.1.

Gilvarry JJ. 1961. The origin of ocean basins and continents. Nature 190: 1048-1053. DOI: 10.1038/1901048a0.

Gore JE. 1909. Astronomical curiosities: Facts and fallacies. London: Chatto \& Windus.

Greene MT. 2015. Alfred Wegener: Science, exploration, and the theory of continental drift. Baltimore: Johns Hopkins University Press.

Gretener PE. 1967. Significance of the rare event in geology. Am Ass Petrol Geol Bull 51: 2197-2206.

Grieve RAF. 1980. Impact bombardment and its role in protocontinental growth on the early earth. Precambrian Research 10: 217-247. DOI: 10.1016/0301-9268(80)90013-3.

Grolier MJ. 1985. Bibliography of terrestrial impact structures. NASA Techn Mem 87567: 1-539. Available from http://ntrs.nasa.gov/ archive/nasa/casi.ntrs.nasa.gov/19860002234.pdf (last consult: 2015/17/10).

Gruithuisen FP. 1844. Naturwissenschaftlich - astronomische Aufsätze und Beobachtungen. II. Beweis von der Grösse der Urmeere. B. Naturwissenschaftlich - astronomischer Theil. Naturwiss-Astron Jb Phys Naturhist Himmelsforsch Geol 7: 36-62.

Gruithuisen FP. 1845. Naturwissenschaftliche Aufsätze und Beobachtungen. II. Verstandesblicke in das Organische des Weltalls. Naturwiss-Astron Jb Phys Naturhist Himmelsforsch Geol 8: 52-96.

Günther S. 1911. Vergleichende Mond- und Erdkunde. Braunschweig: F. Vieweg \& Sohn.

Halley E. 1724. Some considerations about the cause of the universal deluge, laid before the Royal Society, on the 12th of December 1694. Phil Trans 33: 118-123.

Hauslab 2015 FR. von1862. Comparaison géographique, orographique et géologique de la surface terrestre avec celle de la partie visible de la lune. Bull Soc géol Fr 2(19): 778-789.

Heide F. 1934. Kleine Meteoritenkunde. Berlin: Springer. DOI: 10.1007/978-3-642-87172-6.

Hey MH. 1940. Second appendix to the catalogue of meteorites; with special reference to those represented in the collection of the British Museum (Natural History), 2nd. ed. London: Trustees of the British Museum.
Hinks AR. 1933. The monthly record. Meteorite craters. Geogr J 82: 374-377.

Hofmann E. 1841. Geognostische Beobachtung auf einer Reise von Dorpat bis Abo, 1837. Beitr Kennt Russ Reichs Aangrenz, Länder Asiens 4: 97-142.

Högbom AG. 1910. In: Mötet den 3 mars 1910 [Minutes of the Geological Society Stockholm on 3. March 1910] (abstract). Geol Fören Stockholm Förh 32: 482. In Swedish.

Hölder H. 1989. Kurze Geschichte der Geologie und Paläontologie. Berlin: Springer. DOI: 10.1007/978-3-642-61540-5.

Holmes A. 1931. Radioactivity and earth movements. Trans Geol Soc Glasgow 18(1928-1929): 559-606.

Holzmayer JB. 1880. Das Bad Arensburg auf der Insel Oesel. Arensburg: Th. Lange.

Hörz F. 1965. Untersuchungen an Riesgläsern. Beitr Mineral Petr 11: 621-661.

Hoyt WG. 1987. Coon Mountain controversies-Meteor Crater and the development of impact theory. Tucson: Univ. Arizona.

Hsü KJ. 1989. Catastrophic extinctions and the inevitability of the improbable. J Geol Soc 146: 749-734. DOI: 10.1144/ gsjgs.146.5.0749.

Ingalls AG. 1928. A miniature Meteor Crater. Sci Am 139: 45. DOI: 10.1038/scientificamerican0728-45.

Ivanov BA, Melosh HJ. 2003. Impacts do not initiate volcanic eruptions: eruptions near the crater. Geology 31: 869-872. DOI: 10.1130/G19669.1.

Jagt-Yazykova EA, Racki G. 2017. Vladimir P. Amalitsky and Dmitry N. Sobolev - late nineteenth/early twentieth century pioneers of modern concepts of palaeobiogeography, biosphere evolution and mass extinctions. Episodes 40: 189-199. DOI: 10.18814/epiiugs/ 2017/v40i3/017022.

Kaljuvee [written under the name of Kalkun] J. 1922. General Geology. Tallinn: Pihlakas. In Estonian.

Kaljuvee JO. 1933. Die Grossprobleme der Geologie. Tallinn (Reval): F. Wassermann.

Kant I. 1785. Über die Vulkane im Monde. Berlin Monatsschr 5: 199 213.

Kayser E. 1918-1924. Lehrbuch der Geologie, vol. I-IV. Stuttgart: Ferdinand Enke.

Kelly AO. 1985. Impact Geology. Carlsbad, Ca. : [s. n.].

Kelly AO, Dachille F. 1953. Target: Earth - the Role of Large Meteors in Earth Science. Pensacola, Fla.: Pensacola Engraving Co.

Keyes CR. 1907. Volcanic craters in the southwest. Bull Geol Soc Am 17: 721-723.

Kolchinsky EI. 2002. Neocatastrophism and selectionism. The eternal dilemma or the opportunity of the synthesis? (historical-critical notes). Sankt Peterburg: Nauka. In Russian.

Kölbl-Ebert M. 2015. From local patriotism to a planetary perspective: Impact crater research in Germany. 1930s-1970s. Farnham: Ashgate.

Köppen W, Wegener A. 1924. Die Klimate der Geologischen Vorzeit. Berlin: Gebrüder Borntraeger.

Kranz W. 1937. "Krater von Sall" auf Ösel, wahrscheinlich "Meteorkrater". Gerl Beitr Geophys 51: 50-55.

Kraus E, Meyer R. 1928. Nachtrag zu: Untersuchungen über den Krater von Sall auf Ösel. Gerl Beitr Geophys 20: 428-429.

Kraus E, Meyer R, Wegener A. 1928. Untersuchungen über den Krater von Sall auf Ösel. Gerl Beitr Geophys 20: 312-378.

Kraut F. 1969. Uber ein neues Impaktit-Vorkommen im Gebiete von Rochechouart-Chassenon (Départements Haute-Vienne und Charente, Frankreich). Geologica Bavarica 61: 428-450.

Krinov EL. 1960. The Kaalijarv craters. Priroda 1960(7): 55-57. In Russian. 
Krinov EL. 1961. The Kaalijarv meteorite craters on Saaremaa Island, Estonian SSR. Am J Sci 259: 430-440. DOI: 10.2475/ ajs.259.6.430.

Kruse F. 1842. Necrolivonica oder Alterthümer Liv-, Ehst- und Curlands. Dorpat: published by the author.

Kulik LA. 1940. The meteorite crater Kaliyarv. Priroda 1940(12): 63-65. In Russian.

Kuzmin MI, Yarmolyuk VV, Ernst RE. 2016. Tectonic activity of the early Earth (4.56-3.4(2.7?) Ga). Russ Geol Geophys 57: 639-652. DOI: $10.1016 /$ j.rgg.2016.04.003.

La Paz L. 1941. Meteorite craters and the hypothesis of the existence of contraterrene meteorites. Contrib Soc Res Meteorite 2: 244-247. DOI: $10.1111 /$ j.1945-5100.1941.tb00269.x.

Laplace PS. 1796. Exposition du système du monde, vol. 2. Paris : De l'Imprimerie du Cercle-Social.

Lapparent A. de 1897. Le fer natif de Canyon Diablo. Rev Quest Sci 41: 353-383.

Leonard FC. 1946. Authenticated meteorite craters of the world. New Mexico Univ Publ Meteoritics 1: 54.

Linslow O. von 1919. Der Krater von Sall auf Oesel. Centralbl Mineral Geol Paläont 1919: 326-339.

Loit A. 2011. Tallinlase unistus Nobeli rahupreemiast. Acta Historica Tallinensia 16: 136-147. In Estonian.

Losiak A, Wild EM, Geppert WD, Huber MS, Jõeleht A, Kriiska A, et al. 2016. Dating a small impact crater: An age of Kaali crater (Estonia) based on charcoal emplaced within proximal ejecta. Meteorit Planet Sci 51: 681-695.

Luce JWL. von 1827. Wahrheit und Muthmaßung: Beytrag zur Ältesten Geschichte der Insel Oesel. Pernau (Pärnu): Gotthardt Marquardt.

Luce JWL. von 1850. Notizen zur topographischen Geschichte der Insel Oesel. Mitt Geb Gesch Liv-, Est- und Kurlands 5: 439-467.

Magie WF. 1910. Physical notes of Meteor Crater, Arizona. Proc Am Phil Soc 49: 41-48.

Maher HD. 1998. Resurgent ideas as paradigms regained in the history of geology. J Geosci Educ 46: 121-128. DOI: 10.5408/ 1089-9995-46.2.121.

Mallard E, Daubrée GA. 1892. Sur le fer natif de Canyon Diablo. $C R$ Acad Sci Paris 114: 812-814.

Margerie 2015 E. de1913. Deux accidents crateriformes - Crater Lake (Oreg.) et Meteor Crater (Ariz.). Ann Géogr 22: 172-184.

Marvin UB. 1986. Meteorites, the Moon, and the history of geology. $J$ Geol Educ 34: 140-165. DOI: 10.5408/0022-1368-34.3.140.

Meinecke F. 1909. Der Meteorkrater von Canyon Diablo in Arizona und seine Bedeutung für die Entstehung der Mondkrater. Naturwiss Wochenschr 24: 801-810.

Merrill GP. 1908. The Meteor Crater of Canyon Diablo, Arizona; its history, origin and associated meteoritic irons. Smiths Misc Coll 50: 461-498.

Meydenbauer A. 1890. Oberflächenbildung auf Erde und Monde. Sirius 23: 74-79.

Meydenbauer A. 1906. Spuren meteoritischer Aufstürtze in Deutschland. Weltall 7: 90-94.

Meyer MW. 1902. Der Untergang der Erde und die Kosmischen Katastrophen. Betrachtungen über die Zukünftigen Schicksale Unserer Erdenwelt. Berlin: Allgem. Ver. Dtsch. Literatur.

Morozov N. 1930. Meteoritic catastrophes on the Earth and on the Moon. In: Christ, vol. 6, Iz Viekovych Glubin (book 1, part 3). Moscow: Gosydarstvennoje Izdatelstvo (GIZ), pp. 448-486. In Russian. Available from http://www.nlitres.ru/nikolay-morozov/ hristos/ (last consult: 2014/23/03).

Mulder ME. 1911. The explosion of meteors and the origin of the Canyon Diablo meteor crater. De Ingenieur 26(39): 880-885. In Dutch.
Munk JA. 1905. Arizona Sketches. New York: Grafton Press.

Nininger HH. 1933. Our stone pelted planet, a book about meteors and meteorites. Boston: Houghton Mifflin Co.

Nininger HH. 1942. Cataclysm and evolution. Pop Astron 50: 270-272.

Olufsen O. 1914. The transcontinental Excursion 1912 through the United States North America II. Geogr Tidsskr 22: 93-120. In Danish.

Öpik EJ. 1916. A note on the meteoric theory of lunar craters. Mirovedenie 5: 125-134. In Russian. (Translated in Racki et al., 2014, 1869-1874).

Öpik EJ. 1958. On the catastrophic effect of collisions with celestial bodies. Irish Astron J 5: 34-36.

Palmer T. 2003. Perilous planet earth: Catastrophes and catastrophism through the ages. Cambridge: Cambridge Univ. Press.

Palmer D. 2005. Earth time: Exploring the deep past from Victorian England to the Grand Canyon. Chichester: J. Wiley \& Sons.

Partsch J. 1913. Die Transkontinentale Exkursion der Amerikanischen Geographischen Gesellschaft 22. August bis 18. Oktober 1912. Zeitschr Ges Erdk Berlin 1913: 249-272.

Plado J. 2012. Meteorite impact craters and possibly impact-related structures in Estonia. Meteorit Planet Sci 47: 1590-1605. DOI: 10.1111/j.1945-5100.2012.01422.x.

Pokrzywnicki J. 1964. Meteorites of Poland, 6-Meteorites of Morasko. Studia Geol Pol 15: 49-70. In Polish.

Powell JL. 2015. Four revolutions in the Earth Sciences: From heresy to truth. New York: Columbia Univ. Press.

Racki G. 2012a. Ernst Julius Öpik, an undervalued Estonian precursor of the Alvarez impact catastrophism. Acta Palaeont Pol 57: 680. DOI: 10.4202/app.2012.1001.

Racki G. 2012b. The Alvarez impact theory of mass extinction; limits to its applicability and the "great expectations syndrome". Acta Palaeont Pol 57: 681-702. DOI: 10.4202/app.2011.0058.

Racki G. 2015. Catastrophism and neocatastrophism versus cosmic hazard: Ager versus Alvarez; Cuvier versus Laplace. Palaios 30: 432-434. DOI: 10.2110/palo.2015.003.

Racki G, Koeberl C, Viik T, Jagt-Yazykova EA, Jagt JWM. 2014. Ernst Julius Öpik's (1916) note on the theory of explosion cratering on the Moon's surface-The complex case of a long-overlooked benchmark paper. Meteorit Planet Sci 49: 1851-1874. DOI: 10.1111/maps.12367.

Racki G, Jagt JWM, Jagt-Yazykova EA, Koeberl C. 2018. A Dutch contribution to early interpretations of Meteor Crater, Arizona, USA - Marten Edsge Mulder's ignored 1911 paper. Proc Geol Assoc 129: 542-560.

Rampino MR. 2017. Cataclysms: A new geology for the twenty-first century. New York: Columbia University Press.

Rauch A. 2011. Palaeontology. In: Mitchell S, ed. Victorian Britain: An Encyclopedia. Abington: Routledge, pp. 569-570.

Raukas A, Stankowski W. 2010. The Kaali crater field and other geosites of Saaremaa Island (Estonia): the perspectives for a geopark. Geologos 16: 59-68. DOI: 10.2478/v10118-010-0004-z.

Raukas A, Stankowski W. 2011. On the age of the Kaali craters, Island of Saaremaa, Estonia. Baltica 24: 37-44.

Raukas A, Punning JM, Moora T, Kestlane U. 2005. The structure and age of the Kaali Main Crater, Island of Saaremaa, Estonia. In: Koeberl C, Henkel H, eds. Impact Tectonics. Berlin: Springer, pp. 341-355. DOI: 10.1007/3-540-27548-7 13.

Raunet E. 1940. I. Reinwaldi tööde arvustus. Eesti Loodus 8: 215 217. In Estonian.

Reinwald [written as Reinwaldt] I. (with contribution of Luha A.) 1928. Bericht über geologische Untersuchungen am Kaalijärv (Krater von Sall) auf Ösel. Sitzungsber Naturforsch Ges Univ Tartu 25: $30-70$. 
Reinwald JA. 1933. Kaali järv - the meteorite craters on the island of Ösel (Estonia). Tartu Ülik Looduseuur Seltsi Aruanded 30(1932) $1-20$.

Reinwald IA. 1938a. Der Krater von Sall (Kaali järv)-ein Meteorkrater-Feld in Estland. Natur und Volk 68: 16-24.

Reinwald [written as Reinvald] I. 1938b. The finding of meteoritic iron in Estonian craters. a long search richly awarded. SkyMagazine of Cosmic News 2(6): 6-7.

Reinwald [written as Reinvald] IA. 1940. The Kaalijärv meteor craters (Estonia) supplementary research of 1937; discovery of meteoric iron. Tartu Ülik Looduseuur Seltsi Aruanded 45(1938): 81-99.

Richards MA, Alvarez W, Self S, Karlstrom L, Renne PR, Manga M, et al. 2015. Triggering of the largest Deccan eruptions by the Chicxulub impact. Bull Geol Soc Am 127: 1507-1520. DOI: 10.1130/B31167.1.

Rohleder HPT. 1933. Meteor-Krater (Arizona) - Salzpfanne (Transvaal)-Steinheimer Becken. Zeitschr Dtsch Geol Ges 85: 463-468.

Rozet CA. 1846. Extrait d'un mémoire sur la sélénologie. Bull Soc géol Fr 2(3): 262-267.

Rüger L. 1933. Bücherbesprechungen: Kaljuvee J. Die Großprobleme der Geologie.Geogr Zeitschr 39: 427.

Rydzewski B. 1910. Meteor crater in Arizona. Wszechświat 29: 209 213. In Polish.

Schechner Genuth S. 1997. Comets, popular culture, and the birth of modern cosmology. Princeton, NJ: Princeton Univ. Press.

Schmidt F. 1858. Untersuchungen über die silurische Formation von Ehstland, Nord-Livland und Oesel. Archiv Naturk. Liv-, Ehst- und Kurland 2: 1-249.

Schwarz EHL. 1909. The probability of large meteorites having fallen upon the Earth. $J$ Geol 17: 124-135.

Seidlitz W. von 1920. Revolutionen in der Erdgeschichte. Jena, Gustav Fischer.

Sellards EH. 1927. Unusual structural feature in the Plains region of Texas (abstract). Bull Geol Soc Am 38: 149. DOI: 10.1130/GSAB$38-1$

Shoemaker EM. 1962. Interpretation of lunar craters. In: Kopal Z, ed. Physics and Astronomy of the Moon. New York: Academic Press, pp. 283-359.

Sigurdsson H. 1999. Melting the Earth: The history of ideas on volcanic eruptions. Oxford: Oxford Univ. Press.

Sjögren HJ. 1911. On the crater at Canyon Diablo, Arizona, and its connection with the meteor iron fall at the same location. Svenska Vetenskapsakad, Handlingar, Stockholm Arsbok 1911: 237-262. In Swedish.

Sobolev DN. 1928. Earth and life. III. On the causes of extinction of organisms. Kiev: Science-Popular Library of the Ukrainian Department of the Geological Committee. In Russian.

Spencer LJ. 1933. Meteorite craters as topographical features on the earth's surface. Geogr J 81: 227-248.

Spencer LJ, 1938. The Kaalijarv meteorite from the Estonian craters. Mineral Mag 25: 75-80.

Stöffler D, Artemieva NA, Wünnemann K, Reimold WU, Jacob J, Hansen BK, et al. 2013. Ries crater and suevite revisitedobservations and modeling Part I: Observations. Meteorit Planet Sci 48: 515-589. DOI: 10.1111/maps. 12086.

Suess FE. 1901. Die Herkunft der Moldavite und verwandter Gläser. Jb k-k geol Reichsanstalt 50(1900) 193-382.
Tiirmaa R. 1994. Kaali meteorite. Tallinn: Eesti Teaduste Akadeemia Geoloogia Instituut. 104 p. In Estonian.

Tiirmaa R, Czegka W. 1996. The Kaali-crater field at Saaremaa (Ösel, Estonia), geological investigations since 1827 and future perspectives. Meteorit Planet Sci 31(S4): A142-A143. DOI: 10.1111/ j.1945-5100.1996.tb02098.x.

Tilghman BC. 1905. Coon Butte. Arizona. Proc Acad Nat Sci Philadelphia 57: 887-914.

Tilley CE. 1961. Leonard James Spencer, 1870-1959. Biogr Mems Fell R Soc 7: 243-248.

Torrens HS. 1998. No Impact' René Gallant (1906-1985) and his book of 1964 Bombarded Earth (An Essay on the Geological and Biological Effects of huge Meteorite Impacts). Earth Sci Hist 17: 174-189. DOI: 10.17704/eshi.17.2.jk371381461014t6.

Usov MA. 1916. Catastrophes in Earth history. Priroda 5: 437-462. In Russian.

Veski S, Heinsalu A, Poska A, Saarse L, Vassiljev J. 2007. The physical and social effects of the Kaali meteorite impact - a review. In: Bobrowsky PT, Rickman H, eds. Comet/Asteroid Impacts and Human Society. Berlin: Springer, pp. 265-275. DOI: 10.1007/ 978-3-540-32711-0 15.

Vries H. de 1901-1903. Die Mutationstheorie. Versuche und Beobachtungen über die Entstehung von Arten im Pflanzenreich, vol. I-II. Leipzig, Veit.

Wangenheim von Qualen F. 1849. Der Krater bei Sall auf der Insel Oesel. Correspondentzbl Natorforsch Ver Riga 3: 49-68. [Printed in 1849 also in Bull Soc Impér Naturalistes Moscou 22: 204-231, and as separate reprint in Riga: W. F. Häcker, 22 p.].

Wangenheim von Qualen F. 1850. Nachträgliche Bemerkungen über den Explosionskrater bei Sall. Correspondentzbl Natorforsch Ver Riga 3(11) [1849]: 175-180. [Printed also in 1850 as "Noch einige Worte über den Krater von Sall in Bull Soc Impér Naturalistes Moscou 23: 289-296).

Wangenheim von Qualen F. 1852. Nachtraegliche Bemerkungen über den Explosions krater (Erhebungs-Circus-Ring-oder Kesseltahl) von Sall auf der Insel Oesel in Livland. Bull Soc Impér Naturalistes Moscou 25: 136-147.

Ward DC, Carozzi VA. 1984. Geology emerging. A catalog illustrating the history of geology (1500-1850) from a collection in the library of the university of Illinois at Urbana-Champaign. Board of Trustees - University of Illinois.

Watson F. 1936. Meteor craters. Pop Astron 44: 2-17.

Wegener A. 1912. Die Entstehung der Kontinente. Geol Rundsch 3: 276-292. DOI: 10.1007/BF02202896.

Wegener A. 1921. Die Entstehung der Mondkrater. Braunschweig: Friedrich Vieweg und Sohn.

Werner E. 1904. Das Ries in der schwäbisch-fränkischen Alb. Blätt Schwäb Albvereins 16(5): columns 155-168.

Wicander R, Monroe JS. 2009. Historical geology: Evolution of earth and life through time (6 ed.). Belmont, Ca.: Brooks/Cole.

Wilson JT. 1963. Hypothesis of earth's behaviour. Nature 198: 925 929. DOI: $10.1038 / 198925 \mathrm{a} 0$.

Zanetti M, Wilk J. Kukko A, Kaartinen H, Kohv M, Jõeleht A, et al. 2015. The structure of the Kaali impact crater (Estonia) based on 3D Laser Scanning, Electro-Resistivity Tomography, and Sale Hydrocode Modelling. LPI Contrib 1861: 1103. Available from https://www.hou.usra.edu/meetings/gap2015/pdf/1103.pdf (last consult: 2018/01/01).

Cite this article as: Racki G, Viik T, Puura V. 2018. Julius Kaljuvee, Ivan Reinwald, and Estonian pioneering ideas on meteorite impacts and cosmic neocatastrophism in the early 20th century, BSGF - Earth Sciences Bulletin 189: 11. 